\title{
Association of Circulating Metabolites in Plasma or Serum and Risk of Stroke
}

\author{
Meta-analysis From 7 Prospective Cohorts
}

\begin{abstract}
Dina Vojinovic, PhD, Marita Kalaoja, MSc, Stella Trompet, PhD, Krista Fischer, PhD, Martin J. Shipley, MSc, Shuo Li, PhD, Aki S. Havulinna, DSc, Markus Perola, PhD, Veikko Salomaa, MD, PhD, Qiong Yang, PhD, Naveed Sattar, PhD, Pekka Jousilahti, PhD, Najaf Amin, PhD, Claudia L. Satizabal, PhD, Nele Taba, MSc, Behnam Sabayan, PhD, Ramachandran S. Vasan, MD, M. Arfan Ikram, PhD, David J. Stott, MD, Mika Ala-Korpela, PhD, J. Wouter Jukema, PhD, Sudha Seshadri, MD, Johannes Kettunen, PhD, Mika Kivimaki, FMedSci, Tonu Esko, PhD, and Cornelia M. van Duijn, PhD, FMedSci
\end{abstract}

Neurology ${ }^{\circledR}$ 2021;96:e1110-e1123. doi:10.1212/WNL.0000000000011236

\author{
Correspondence \\ Dr. van Duijn \\ Cornelia.vanDuijn@ \\ ndph.ox.ac.uk
}

\begin{abstract}
Objective

To conduct a comprehensive analysis of circulating metabolites and incident stroke in large prospective population-based settings.

\section{Methods}

We investigated the association of metabolites with risk of stroke in 7 prospective cohort studies including 1,791 incident stroke events among 38,797 participants in whom circulating metabolites were measured by nuclear magnetic resonance technology. The relationship between metabolites and stroke was assessed with Cox proportional hazards regression models. The analyses were performed considering all incident stroke events and ischemic and hemorrhagic events separately.
\end{abstract}

\section{Results}

The analyses revealed 10 significant metabolite associations. Amino acid histidine (hazard ratio [HR] per SD $0.90,95 \%$ confidence interval [CI $\left.] 0.85,0.94 ; p=4.45 \times 10^{-5}\right)$, glycolysis-related metabolite pyruvate (HR per SD 1.09, 95\% CI 1.04, 1.14; $p=7.45 \times 10^{-4}$ ), acute-phase reaction marker glycoprotein acetyls (HR per SD 1.09, 95\% CI 1.03, 1.15; $p=1.27 \times 10^{-3}$ ), cholesterol in high-density lipoprotein (HDL) 2, and several other lipoprotein particles were associated with risk of stroke. When focused on incident ischemic stroke, a significant association was observed with phenylalanine (HR per SD 1.12, 95\% CI 1.05, $1.19 ; p=4.13 \times 10^{-4}$ ) and total and free cholesterol in large HDL particles.

\section{Conclusions}

We found association of amino acids, glycolysis-related metabolites, acute-phase reaction markers, and several lipoprotein subfractions with the risk of stroke. These findings support the potential of metabolomics to provide new insights into the metabolic changes preceding stroke.

From the Department of Epidemiology (D.V., N.A., M.A.I., C.M.v.D.), Erasmus MC, University Medical Center, Rotterdam, the Netherlands; Computational Medicine (M. Kalaoja, M.A.K., J.K.), Faculty of Medicine, University of Oulu and Biocenter Oulu, Finland; Departments of Gerontology and Geriatrics (S.T.), and Cardiology (S.T., J.W.J.), Leiden University Medical Center, the Netherlands; Estonian Genome Centre (K.F., N.T., T.E.), Institute of Genomics, and Institute of Molecular and Cell Biology (N.T.), University of Tartu, Estonia; Department of Epidemiology and Public Health (M.J.S., M. Kivimaki), UCL, London, UK; Department of Biostatistics (S.L., O.Y.), School of Public Health, Boston University, MA; Department of Public Health Solutions (A.S.H., M.P., V.S., P.J., J.K.), Finnish Institute for Health and Welfare; Institute for Molecular Medicine Finland (A.S.H., M.P.), University of Helsinki; BHF Glasgow Cardiovascular Research Centre (N.S.), Faculty of Medicine, UK; Department of Neurology (B.S.), Feinberg School of Medicine, Northwestern University, Chicago, IL; Framingham Heart Study (C.L.S., R.S.V., S.S.), MA; Department of Radiology and Nuclear Medicine (M.A.I.), Erasmus MC, University Medical Center, Rotterdam, the Netherlands; Institute of Cardiovascular and Medical Sciences (D.J.S.), College of Medical, Veterinary and Life Sciences, University of Glasgow, UK; Systems Epidemiology (M.A.-K.), Baker Heart and Diabetes Institute, Melbourne, Victoria, Australia; NMR Metabolomics Laboratory (M.A.-K.), School of Pharmacy, University of Eastern Finland, Kuopio; Population Health Science (M.A.-K.) Bristol Medical School, and Medical Research Council Integrative Epidemiology Unit (M.A.-K.), University of Bristol, UK; Department of Epidemiology and Preventive Medicine (M.A.K.), School of Public Health and Preventive Medicine, Faculty of Medicine, Nursing and Health Sciences, The Alfred Hospital, Monash University, Melbourne, Victoria, Australia; Netherlands Heart Institute (I.W.J.), Utrecht, the Netherlands; Department of Neurology (C.L.S., S.S.), Boston University School of Medicine; Broad Institute of MIT and Harvard (T.E.), Boston, MA; Glenn Biggs Institute for Alzheimer's and Neurodegenerative Diseases (C.L.S., S.S.), UT Health San Antonio, TX; Nuffield Department of Population Health (C.M.v.D.), University of Oxford, UK. D.V. is currently at the Department of Biomedical Data Sciences, Section of Molecular Epidemiology, Leiden University Medical Center, the Netherlands, and K.F. is currently at the Institute of Mathematics and Statistics, University of Tartu, Estonia.

Go to Neurology.org/N for full disclosures. Funding information and disclosures deemed relevant by the authors, if any, are provided at the end of the article. 


\section{Glossary}

BMI = body mass index; CI = confidence interval; DILGOM = Dietary, Lifestyle and Genetic Determinants of Obesity and Metabolic Syndrome; EGCUT = Estonian biobank; FHS = Framingham Heart Study; FINRISK97 = FINRISK study 1997; HDL = high-density lipoprotein; HR = hazard ratio; ICD = International Classification of Diseases; LDL = low-density lipoprotein; NMR = nuclear magnetic resonance; PROSPER = Prospective Study of Pravastatin in the Elderly at Risk.

Stroke is a leading cause of death and serious long-term disability worldwide. ${ }^{1}$ The majority of strokes are of the ischemic type, while the hemorrhagic type occurs less often but is associated with higher mortality risk. ${ }^{1,2}$ Stroke risk is determined by various modifiable risk factors such as hypertension, diabetes mellitus, cardiovascular disease, smoking, and obesity, whereas the association of stroke with cholesterol and its subfractions has shown inconsistent results. ${ }^{1-5}$ Opportunities for therapeutic interventions in patients with stroke depend on the type of stroke and rely on brain imaging techniques. ${ }^{6}$ Despite advances in brain imaging techniques, costs are still high, availability is limited, and not all patients show a relevant lesion on neuroimaging. ${ }^{6,7}$ New technology is needed to identify highrisk patients, to understand the etiology of stroke, and to develop future prevention strategies. Detailed profiling of metabolic status can provide insights into metabolic changes that lead to a higher risk of stroke. Because the metabolome reflects both genome and exposome, including exposures to risk factors that determine the risk of stroke, this new -omics technology may open new avenues for stroke prevention. To date, only a few studies have analyzed metabolic disturbances in stroke and identified various metabolites to be associated with stroke. ${ }^{8-10}$ These studies are based on relatively small samples or were performed on participants of non-European ancestry. ${ }^{11}$ The most comprehensive study to date was a nested case-control study conducted within the China Kadoorie Biobank including 1,146 patients with ischemic stroke and 1,138 patients with intracerebral hemorrhage. ${ }^{11}$ The study reported an association between lipids and lipoprotein particles of various sizes with ischemic stroke but not with hemorrhage. ${ }^{11}$ Furthermore, the study identified glycoprotein acetyls, ketone bodies, glucose, and docosahexaenoic acid to be associated with both ischemic and hemorrhagic stroke. ${ }^{11}$

Because large metabolomics studies of stroke in persons of European origin are lacking and data from well-established prospective cohort studies are limited, the aim of our study is to conduct a comprehensive analysis of circulating metabolites and incident stroke in large prospective population-based settings involving 1,791 incident stroke events among 38,797 participants of European origin.

\section{Methods}

\section{Standard Protocol Approvals, Registrations, and Patient Consents}

Each of the participating studies received approval by local ethical committees or institutional review boards (data available from Dryad [additional Methods in Additional Information file), doi.org/10.5061/dryad.kh1893239). All participants provided written informed consent.

\section{Study Population}

Our study population included 38,797 participants from 7 cohorts, including the Rotterdam Study, Whitehall II study (Whitehall II), the national FINRISK study 1997 (FINRISK97), Dietary, Lifestyle and Genetic Determinants of Obesity and Metabolic Syndrome (DILGOM), Prospective Study of Pravastatin in the Elderly at Risk (PROSPER), Estonian biobank (EGCUT), and the Framingham Heart Study (FHS). A description of participating studies is available from Dryad (additional Methods in Additional Information file, doi.org/10.5061/dryad.kh1893239).

\section{Stroke Assessment}

Details on stroke assessment are available from Dryad (additional Methods in Additional Information file, doi.org/10.5061/ dryad.kh1893239). The incident stroke events were assessed through follow-up of health records, while in some studies, additional periodic visits to research centers were used (e.g., Rotterdam Study, FHS). Participants of the Rotterdam Study were monitored for incident stroke through an automated linkage of medical records from general practitioners with the study database. ${ }^{12}$ Incident stroke events in the Whitehall II study were ascertained through linkage to electronic records from hospitalizations due to stroke and national statistics death registries, ${ }^{13,14}$ whereas in the FINRISK and DILGOM studies, linkage to national health registries was used (biorxiv.org/content/early/2018/03/12/280677). Ascertainment of incident stroke events in EGCUT was also performed through linkage to electronic records from multiple databases (thl.fi/publications/ morgam/cohorts/full/estonia/est-esta.htm), while information regarding domiciliary visits or hospitalizations associated with possible cardiovascular events, including stroke, and on all deaths was used for classification of study endpoints in PROSPER ${ }^{15}$ In the FHS, incident clinical stroke was identified as part of ongoing clinic and hospital surveillance with additional stroke surveillance by annual phone health updates and collaboration with primary care physicians and local emergency departments. ${ }^{16,17}$ Participants with a history of stroke at baseline were excluded from the analyses.

\section{Baseline Clinical Characteristics}

The baseline clinical characteristics included assessment of blood pressure, plasma glucose levels, smoking status, weight, and height. Hypertension was defined as a systolic blood pressure $\geq 140 \mathrm{mmHg}$, diastolic blood pressure $\geq 90 \mathrm{mmHg}$, 
or use of antihypertensive medication or based on general practitioner diagnosis, medication reimbursement or ICD diagnosis (I10/401/491, ICD-10/9/8) from hospital discharge register or cause of death register, or self-report. Diabetes was defined as fasting plasma glucose levels $>7 \mathrm{mmol}$ / $\mathrm{L}$ or use of medication indicated for the treatment of diabetes. Body mass index (BMI) was calculated as weight in kilograms divided by square of heights in meters.

\section{Metabolite Quantification}

Circulating metabolites were quantified with a high-throughput nuclear magnetic resonance (NMR) technology. In all participating studies except the FHS, the Nightingale Health metabolomics platform (Helsinki, Finland) was used for simultaneous quantification of a wide range of metabolites, including routine lipids, 14 lipoprotein subclasses and their lipids (esterified cholesterol, free cholesterol, total cholesterol, triglycerides, phospholipids, and total lipids), fatty acids, amino acids, ketone bodies, and various glycolysis precursors. A detailed description of the methodology has been provided previously. ${ }^{18,19}$ The Nightingale quality control procedures were applied to the data from each cohort. The Nightingale automated data processing and quality control procedures included safety checks for unexpected metabolite signals. For each sample, integrated quality procedures verified the sample quality by reporting signs of degradation and contamination issues. If a metabolite concentration was below the limit of quantification, due to either biological reasons or external compounds interfering with quantification, but above the limit of detection, the metabolite value was presented as 0 . The Nightingale quality control procedure did not have an upper limit for quantified concentrations except for high lactate and high pyruvate, which were established irregularities arising from suboptimal sample collection procedure. Other high values were reported as they are, meaning that high concentrations were not excluded because in some context high biomarker concentration may be biologically and physiologically relevant and provide valuable molecular insight into a disease or an outcome. Every metabolite that has been reported in the results file has passed this strict quality control procedure. No additional single-cohort quality control was applied except for the EGCUT cohort in which metabolites that were detected in the large majority (at least 95\%) of the cohort were included while individuals with missing values in $>10 \%$ of the metabolites were excluded from the analyses. In the FHS, lipoprotein subclasses were measured by proton NMR spectroscopic assay (LipoScience, Raleigh, NC) ${ }^{20,21}$ Blood samples were collected after overnight fasting in all studies except for FINRISK97, in which the samples were collected after 4 hours of fasting (semifasting state). ${ }^{22,23}$ The sample material was EDTA-plasma in the Rotterdam Study, FHS, and EGCUT, whereas the serum was used in FINRISK97, DILGOM, PROSPER, and Whitehall II. $^{22-25}$ The EDTA-plasma/serum samples were stored at either $-80^{\circ} \mathrm{C}$ or $-70^{\circ} \mathrm{C}$. The duration of sample storage ranged from 2 to 9 years in EGCUT and 8 years in DILGOM to 11 years in Rotterdam Study, 15 years in FINRISK97, and 15 to 20 years in PROSPER. There were 147 primary nonderived metabolite measurements quantified in absolute concentration units that were further analyzed in this study (data available from Dryad, additional table 1, doi.org/10.5061/dryad. kh1893239). The descriptive statistics of metabolites were coherent across the cohort (cohort-specific descriptive statistics are available from Dryad (additional table 2).

\section{Statistical Analyses}

To obtain an approximately normal distribution, all metabolites measurements were natural logarithmic transformed before the analyses. Because some of the metabolite values in our datasets were below the limit of quantification and therefore presented as 0,1 was added to all values of the metabolites before the transformation. The metabolite measurements were subsequently scaled to SD units (mean 0, SD 1) to enable comparison of results for measures with different units and across wide ranges of concentrations. The relationship between metabolites and stroke was assessed with Cox proportional hazards regression models. The analyses were performed while adjusted for age, sex, BMI, lipid-lowering medication, and study-specific covariates if needed (model 1). The associations were further adjusted for smoking status, diabetes, and hypertension (model 2). Proportional hazard assumption was tested in EGCUT and FINRISK97. Violation of this assumption was observed for 7 metabolites (noted with an asterisk in additional table 1, doi.org/10.5061/dryad. kh1893239). None of these metabolites showed statistically significant association with incident stroke in our analyses. To overcome the problem of false positives due to differences in study design, sampling, storage, or metabolite assessment, we did not pool and analyze the data of different studies jointly. Rather, we have analyzed individual studies and combined the findings using the meta-analysis. The summary statistics results of participating studies were combined using inverse varianceweighted fixed-effect meta-analysis in METAL. ${ }^{26}$ The heterogeneity of effects was assessed by $I^{2}$, which indicates the percentage of variance in the meta-analysis attributable to study heterogeneity. ${ }^{26,27}$ All hazard ratios (HRs) of continuous variables are expressed per $1 \mathrm{SD}$ of the transformed variable. The analyses were performed considering all incident stroke events and ischemic and hemorrhagic events separately.

Because most of the 147 metabolite measures are highly correlated, we estimated the number of independent tests in the correlation matrix using the previously described method of $\mathrm{Li}$ and Ji. ${ }^{28}$ Subsequently, the number of independent tests was used for calculation of Bonferroni-corrected $p$ value $(p=$ $0.05 / 30$ independent metabolites $=1.7 \times 10^{-3}$ ).

\section{Data Availability}

Data are available on request. Interested researchers may contact the corresponding author.

\section{Results}

The baseline descriptive characteristics of study participants are shown in table 1 . In total, 1,791 incident stroke events 


\begin{tabular}{|c|c|c|c|c|c|c|c|c|c|c|c|c|c|c|}
\hline \multirow[b]{2}{*}{ Variable $^{a}$} & \multicolumn{2}{|c|}{ Rotterdam Study } & \multicolumn{2}{|c|}{ Whitehall II ${ }^{\mathbf{b}}$} & \multicolumn{2}{|l|}{ FINRISK97 } & \multicolumn{2}{|l|}{ DILGOM } & \multicolumn{2}{|l|}{ PROSPER } & \multicolumn{2}{|l|}{ EGCUT } & \multicolumn{2}{|l|}{ FHS } \\
\hline & $\begin{array}{l}\text { Incident } \\
\text { Cases }\end{array}$ & Controls & $\begin{array}{l}\text { Incident } \\
\text { Cases }\end{array}$ & Controls & $\begin{array}{l}\text { Incident } \\
\text { Cases }\end{array}$ & Controls & $\begin{array}{l}\text { Incident } \\
\text { Cases }\end{array}$ & Controls & $\begin{array}{l}\text { Incident } \\
\text { Cases }\end{array}$ & Controls & $\begin{array}{l}\text { Incident } \\
\text { Cases }\end{array}$ & Controls & $\begin{array}{l}\text { Incident } \\
\text { Cases }\end{array}$ & Controls \\
\hline No. & 257 & 2,308 & 197 & 5,792 & 474 & 6,384 & 107 & 4,424 & 197 & 4,627 & 308 & 10,268 & 251 & 3,203 \\
\hline Age, y & $76.9(6.2)$ & $75.0(6.1)$ & $59.4(5.9)$ & $55.6(6)$ & $59.6(10.4)$ & $\begin{array}{l}47.0 \\
(12.9)\end{array}$ & $62.0(10.4)$ & $\begin{array}{l}51.9 \\
(13.5)\end{array}$ & $75.9(3.7)$ & $75.2(3.3)$ & $66.3(12.5)$ & $\begin{array}{l}44.5 \\
(17.1)\end{array}$ & $58.1(9.0)$ & $\begin{array}{l}51.7 \\
(10.1)\end{array}$ \\
\hline Women, \% & 54.1 & 58 & 25.4 & 29.1 & 38.6 & 52.6 & 42.1 & 53.7 & 54 & 52.2 & 54.9 & 63.3 & 47.4 & 51.4 \\
\hline Current smoking, \% & 15.2 & 13 & 15.7 & 9.4 & 24.5 & 23.7 & 21.5 & 17.4 & 28.9 & 27.1 & 17.5 & 29.9 & 24.9 & 24.6 \\
\hline Diabetes, \% & 17.9 & 14.3 & 8.6 & 4.4 & 16.9 & 4.9 & 15.9 & 8.9 & 18.3 & 10.6 & 35.4 & 7.7 & 15.9 & 5.0 \\
\hline Hypertension, \% & 85.6 & 81.0 & 41.1 & 28.0 & 48.9 & 21 & 43 & 16.5 & 58.9 & 62.5 & 66.2 & 24.4 & 60.2 & 34.2 \\
\hline $\begin{array}{l}\text { Systolic blood } \\
\text { pressure, mmHg }\end{array}$ & $\begin{array}{l}156.8 \\
(23.9)\end{array}$ & $\begin{array}{l}151.4 \\
(20.1)\end{array}$ & $\begin{array}{l}127.4 \\
(16.3)\end{array}$ & $\begin{array}{l}122.9 \\
(16.5)\end{array}$ & $\begin{array}{l}147.7 \\
(22.3)\end{array}$ & $\begin{array}{l}134.7 \\
(19.2)\end{array}$ & $\begin{array}{l}149.8 \\
(23.7)\end{array}$ & $\begin{array}{l}136.4 \\
(20.2)\end{array}$ & $\begin{array}{l}157.1 \\
(21.9)\end{array}$ & $\begin{array}{l}154.5 \\
(21.8)\end{array}$ & $\begin{array}{l}142.8 \\
(18.8)\end{array}$ & $\begin{array}{l}125.7 \\
(16.9)\end{array}$ & $\begin{array}{l}137.8 \\
(20.8)\end{array}$ & $\begin{array}{l}126.2 \\
(18.5)\end{array}$ \\
\hline $\begin{array}{l}\text { Diastolic blood } \\
\text { pressure, mmHg }\end{array}$ & $79.7(12.4)$ & $\begin{array}{l}79.2 \\
(11.1)\end{array}$ & $78.3(10.2)$ & $\begin{array}{l}77.5 \\
(10.5)\end{array}$ & 86.1 (11.9) & $\begin{array}{l}81.9 \\
(11.2)\end{array}$ & $83.1(13.6)$ & $\begin{array}{l}79.3 \\
(11.0)\end{array}$ & $84.6(11.8)$ & $\begin{array}{l}83.7 \\
(11.4)\end{array}$ & $83.4(10.9)$ & $\begin{array}{l}77.6 \\
(10.7)\end{array}$ & $81.6(10.4)$ & 78.9 (9.9) \\
\hline $\begin{array}{l}\text { Antihypertensive } \\
\text { medication, } \%^{\mathrm{c}}\end{array}$ & 51 & 47.1 & 21.8 & 12.3 & 27.4 & 11.5 & 34.6 & 22.1 & 70.6 & 74.4 & 69.5 & 24.3 & 36.3 & 16.4 \\
\hline BMI, $\mathrm{kg} / \mathrm{m}^{2}$ & $27.2(3.5)$ & $27.4(4.2)$ & $26.2(4.2)$ & $26.0(3.9)$ & $28.4(4.8)$ & $26.5(4.5)$ & $28.0(5.0)$ & $27.2(4.8)$ & $26.5(4.1)$ & $26.9(4.2)$ & $29.1(5.7)$ & $26.4(5.4)$ & $27.6(5.1)$ & $26.7(4.8)$ \\
\hline Follow-up time, y & $5.7(3.5)$ & $9.8(3.5)$ & $12.5(4.9)$ & $18.2(3.0)$ & $15.0(4.2)$ & $16.9(3.0)$ & $7.25(1.5)$ & $7.75(0.7)$ & $1.9(1.0)$ & $3.3(0.5)$ & $6.9(3.1)$ & $8.9(1.8)$ & $14.7(7.0)$ & $22.4(6.0)$ \\
\hline $\begin{array}{l}\text { Total cholesterol, } \\
\mathrm{mmol} / \mathrm{L}\end{array}$ & $5.5(1.0)$ & $5.6(1.0)$ & $5.8(1.1)$ & $5.9(1.1)$ & $5.8(1.1)$ & $5.52(1.1)$ & $5.23(1.0)$ & $5.28(1)$ & $5.64(0.9)$ & $5.68(0.9)$ & $6.0(1.2)$ & $5.7(1.2)$ & $5.6(1.1)$ & $5.3(1.0)$ \\
\hline $\begin{array}{l}\text { HDL cholesterol, } \\
\mathrm{mmol} / \mathrm{L}\end{array}$ & $1.4(0.4)$ & $1.5(0.4)$ & $1.5(0.4)$ & $1.5(0.4)$ & $1.3(0.3)$ & $1.4(0.4)$ & $1.4(0.4)$ & $1.4(0.4)$ & $1.3(0.3)$ & $1.3(0.4)$ & $1.5(0.4)$ & $1.6(0.5)$ & $1.2(0.4)$ & $1.3(0.4)$ \\
\hline $\begin{array}{l}\text { LDL cholesterol, } \\
\mathrm{mmol} / \mathrm{L}\end{array}$ & NA & NA & $3.8(1.0)$ & $3.9(0.9)$ & $3.7(0.9)$ & $3.5(0.9)$ & $3.1(0.8)$ & $3.2(0.9)$ & $3.8(0.8)$ & $3.8(0.8)$ & $2.5(0.7)$ & $2.3(0.6)$ & $3.6(1.0)$ & $3.4(0.9)$ \\
\hline $\begin{array}{l}\text { Triglycerides, } \\
\mathrm{mmol} / \mathrm{L}\end{array}$ & NA & NA & $1.3(0.8)$ & $1.4(0.9)$ & $1.8(1.1)$ & $1.5(1.0)$ & $1.5(0.8)$ & $1.4(0.9)$ & $1.6(0.7)$ & $1.5(0.7)$ & $1.9(1.0)$ & $1.6(0.9)$ & $1.7(1.2)$ & $1.4(1.2)$ \\
\hline $\begin{array}{l}\text { Lipid-lowering } \\
\text { medication, \% }\end{array}$ & 21.4 & 20.6 & 5.1 & 3.0 & 7.8 & 3.1 & 25.2 & 14.7 & 52.3 & 49.5 & 13.6 & 4.7 & 6.0 & 3.7 \\
\hline $\begin{array}{l}\text { Coronary heart disease, } \\
\%\end{array}$ & 13.6 & 10.8 & 11.7 & 5.9 & 9.1 & 1.9 & 5.6 & 2.9 & 16.8 & 13.1 & 35.1 & 9.2 & 12.4 & 5.7 \\
\hline \multicolumn{15}{|l|}{ Stroke } \\
\hline Hemorrhagic, No (\%) & $32(12.5)$ & - & $48(24.4)$ & - & $69(14.6)$ & - & $23(21.5)$ & - & - & - & 45 (14.6) & - & $30(12)$ & - \\
\hline
\end{tabular}


were observed among 38,797 participants across the 7 cohorts. The mean follow-up time ranged from 2 years in PROSPER, 6 years in the Rotterdam Study, and 7 years in EGCUT and DILGOM to 13 years in Whitehall II and 15 years in FINRISK97 and FHS.

The association analysis between circulating metabolites and all incident stroke revealed 27 significant metabolite associations $\left(p<1.7 \times 10^{-3}\right)$ in model 1 , which are shown in table 2 . After further adjustment for hypertension status, diabetes, and smoking, 7 metabolite associations remained significant after correction for multiple testing (table 2 and figure). These included the amino acid histidine (HR 0.90, 95\% confidence interval $\left.[\mathrm{CI}] 0.85,0.94 ; p=4.45 \times 10^{-5}\right)$ and cholesterol in high-density lipoprotein (HDL) 2 (HR 0.91, 95\% CI 0.87, $\left.0.97 ; p=1.41 \times 10^{-3}\right)$, which were associated with a lower risk of stroke, and glycolysis-related metabolite pyruvate (HR $1.09,95 \%$ CI 1.04, 1.14; $\left.p=7.45 \times 10^{-4}\right)$ and acute-phase reaction markers glycoprotein acetyls (HR 1.09, 95\% CI 1.03, $1.15 ; p=1.27 \times 10^{-3}$ ), which were associated with higher risk of stroke, and several lipoprotein particles, including HDL and low-density lipoprotein (LDL) subfractions (table 2). Cholesterol in medium HDL was associated with lower risk (HR 0.92, 95\% CI 0.87, 0.97; $p=1.35 \times 10^{-3}$ ) whereas triglycerides in medium and large LDL were associated with a higher risk (HR 1.09, 95\% CI 1.03, 1.14; $p=1.67 \times 10^{-3}$ and HR 1.09, 95\% CI 1.03, 1.14; $p=1.19 \times 10^{-3}$, respectively; table 2 ) of stroke. The direction of effect across the cohorts showed no evidence of a single cohort driving the associations (data available from Dryad [additional figure 1 in Additional Information file, doi.org/10.5061/dryad.kh1893239). Whereas the Whitehall II study showed the opposite direction of effect for apolipoprotein A, HDL, and HDL2 cholesterol, the findings showed a general spread for most HDL subfractions.

When we stratified the analysis by stroke type, we observed differences between ischemic and hemorrhagic stroke events (table 3). Amino acid histidine and cholesterol in HDL2 were associated with decreased risk of ischemic but not hemorrhagic incident stroke (table 3). Differences were also observed for glycolysis-related metabolite pyruvate and acutephase inflammation marker glycoprotein acetyls, which were associated with increased risk of ischemic but not hemorrhagic stroke (table 3). Associations between incident stroke events and LDL and HDL particles of various sizes were observed only in the overall analysis, suggesting contributions from both stroke subtypes (table 3).

Furthermore, a significant association was observed between phenylalanine levels and increased risk of incident ischemic stroke (HR 1.12, 95\% CI 1.05, 1.19; $p=4.13 \times 10^{-4}$ ). We also observed association of circulating levels of cholesterol (HR $0.89,95 \%$ CI $0.84,0.95 ; p=9.00 \times 10^{-4}$ ) and free cholesterol in large HDL cholesterol (HR 0.89, 95\% CI 0.82, 0.95; $p=$ $1.33 \times 10^{-3}$ ) with decreased risk of ischemic stroke. No metabolite surpassed the significant threshold in the analysis for hemorrhagic stroke. 
Table 2 Results of Association Analysis Showing the Significant Metabolite Associations With Overall Incident Stroke

\begin{tabular}{|c|c|c|c|c|c|c|c|c|c|c|c|c|}
\hline \multirow[b]{2}{*}{ Metabolite } & \multicolumn{6}{|c|}{ Model 1} & \multicolumn{6}{|c|}{ Model 2} \\
\hline & No. & $\begin{array}{l}\text { No. } \\
\text { Cases }\end{array}$ & HR & $\mathrm{Cl}$ & $I^{2 \mathrm{~b}}$ & $p$ Value & No. & $\begin{array}{l}\text { No. } \\
\text { Cases }\end{array}$ & HR & $\mathrm{Cl}$ & $I^{2}$ & $p$ Value \\
\hline Phenylalanine & 35,091 & 1,527 & 1.11 & $\begin{array}{l}1.06 \\
1.17\end{array}$ & 44.4 & $\begin{array}{l}4.88 \mathrm{E}- \\
05\end{array}$ & 35,036 & 1,524 & 1.08 & $\begin{array}{l}1.03 \\
1.14\end{array}$ & 17 & $\begin{array}{l}3.36 \mathrm{E}- \\
03\end{array}$ \\
\hline Histidine $^{a}$ & 35,017 & 1,526 & 0.89 & $\begin{array}{l}0.84 \\
0.93\end{array}$ & 40.7 & $\begin{array}{l}7.94 \mathrm{E}- \\
06\end{array}$ & 34,962 & 1,523 & 0.90 & $\begin{array}{l}0.85 \\
0.94\end{array}$ & 30.2 & $\begin{array}{l}4.45 \mathrm{E}- \\
05\end{array}$ \\
\hline Plasma-ApoA1 & 35,107 & 1,529 & 0.91 & $\begin{array}{l}0.86 \\
0.96\end{array}$ & 18.3 & $\begin{array}{l}7.14 \mathrm{E}- \\
04\end{array}$ & 35,052 & 1,526 & 0.94 & $\begin{array}{l}0.88 \\
0.99\end{array}$ & 30.3 & $\begin{array}{l}1.79 \mathrm{E}- \\
02\end{array}$ \\
\hline HDL-cholesterol & 35,107 & 1,529 & 0.89 & $\begin{array}{l}0.84 \\
0.94\end{array}$ & 65.8 & $\begin{array}{l}2.89 \mathrm{E}- \\
05\end{array}$ & 35,052 & 1,526 & 0.92 & $\begin{array}{l}0.87 \\
0.97\end{array}$ & 68.3 & $\begin{array}{l}3.20 \mathrm{E}- \\
03\end{array}$ \\
\hline HDL2-cholesterol ${ }^{a}$ & 35,107 & 1,529 & 0.88 & $\begin{array}{l}0.84 \\
0.93\end{array}$ & 66.3 & $\begin{array}{l}9.13 \mathrm{E}- \\
06\end{array}$ & 35,052 & 1,526 & 0.91 & $\begin{array}{l}0.87 \\
0.97\end{array}$ & 69.1 & $\begin{array}{l}1.41 \mathrm{E}- \\
03\end{array}$ \\
\hline IDL-triglycerides & 38,561 & 1,780 & 1.10 & $\begin{array}{l}1.05 \\
1.16\end{array}$ & 38.6 & $\begin{array}{l}6.06 \mathrm{E}- \\
05\end{array}$ & 38,494 & 1,775 & 1.07 & $\begin{array}{l}1.02, \\
1.12\end{array}$ & 44 & $\begin{array}{l}9.91 \mathrm{E}- \\
03\end{array}$ \\
\hline LDL-triglycerides & 35,107 & 1,529 & 1.12 & $\begin{array}{l}1.06 \\
1.18\end{array}$ & 2.5 & $\begin{array}{l}3.93 \mathrm{E}- \\
05\end{array}$ & 35,052 & 1,526 & 1.08 & $\begin{array}{l}1.03 \\
1.14\end{array}$ & 20.1 & $\begin{array}{l}2.47 \mathrm{E}- \\
03\end{array}$ \\
\hline Glucose & 34,980 & 1,524 & 1.15 & $\begin{array}{l}1.10 \\
1.20\end{array}$ & 13.7 & $\begin{array}{l}7.81 \mathrm{E}- \\
11\end{array}$ & 34,925 & 1,521 & 1.06 & $\begin{array}{l}1.01 \\
1.11\end{array}$ & 0 & $\begin{array}{l}1.87 \mathrm{E}- \\
02\end{array}$ \\
\hline Lactate & 35,100 & 1,529 & 1.12 & $\begin{array}{l}1.07 \\
1.18\end{array}$ & 56.7 & $\begin{array}{l}1.11 \mathrm{E}- \\
05\end{array}$ & 35,045 & 1,526 & 1.08 & $\begin{array}{l}1.02, \\
1.13\end{array}$ & 29.1 & $\begin{array}{l}5.09 \mathrm{E}- \\
03\end{array}$ \\
\hline Pyruvate $^{a}$ & 24,423 & 1,205 & 1.13 & $\begin{array}{l}1.08 \\
1.18\end{array}$ & 48.6 & $\begin{array}{l}1.37 \mathrm{E}- \\
07\end{array}$ & 24,368 & 1,202 & 1.09 & $\begin{array}{l}1.04 \\
1.14\end{array}$ & 13.6 & $\begin{array}{l}7.45 \mathrm{E}- \\
04\end{array}$ \\
\hline Glycoprotein acetyls ${ }^{a}$ & 35,101 & 1,529 & 1.15 & $\begin{array}{l}1.09 \\
1.21\end{array}$ & 43.2 & $\begin{array}{l}1.25 \mathrm{E}- \\
07\end{array}$ & 35,046 & 1,526 & 1.09 & $\begin{array}{l}1.03 \\
1.15\end{array}$ & 38.9 & $\begin{array}{l}1.27 \mathrm{E}- \\
03\end{array}$ \\
\hline HDL-diameter & 35,107 & 1,529 & 0.89 & $\begin{array}{l}0.84 \\
0.94\end{array}$ & 49 & $\begin{array}{l}3.05 \mathrm{E}- \\
05\end{array}$ & 35,052 & 1,526 & 0.92 & $\begin{array}{l}0.87 \\
0.98\end{array}$ & 61.6 & $\begin{array}{l}6.73 \mathrm{E}- \\
03\end{array}$ \\
\hline S-HDL-triglycerides & 35,108 & 1,529 & 1.11 & $\begin{array}{l}1.06 \\
1.17\end{array}$ & 48.4 & $\begin{array}{l}6.80 \mathrm{E}- \\
05\end{array}$ & 35,053 & 1,526 & 1.07 & $\begin{array}{l}1.01 \\
1.12\end{array}$ & 53.5 & $\begin{array}{l}1.97 \mathrm{E}- \\
02\end{array}$ \\
\hline M-HDL-cholesterol ${ }^{a}$ & 38,560 & 1,780 & 0.89 & $\begin{array}{l}0.85 \\
0.94\end{array}$ & 56 & $\begin{array}{l}2.07 \mathrm{E}- \\
05\end{array}$ & 38,493 & 1,775 & 0.92 & $\begin{array}{l}0.87 \\
0.97\end{array}$ & 50.4 & $\begin{array}{l}1.35 \mathrm{E}- \\
03\end{array}$ \\
\hline $\begin{array}{l}\text { M-HDL-cholesterol } \\
\text { esters }\end{array}$ & 35,106 & 1,529 & 0.90 & $\begin{array}{l}0.85 \\
0.95\end{array}$ & 60.1 & $\begin{array}{l}2.05 \mathrm{E}- \\
04\end{array}$ & 35,051 & 1,526 & 0.92 & $\begin{array}{l}0.87 \\
0.97\end{array}$ & 57.8 & $\begin{array}{l}3.73 \mathrm{E}- \\
03\end{array}$ \\
\hline M-HDL-free cholesterol & 35,106 & 1,529 & 0.91 & $\begin{array}{l}0.86 \\
0.96\end{array}$ & 56 & $\begin{array}{l}7.33 \mathrm{E}- \\
04\end{array}$ & 35,051 & 1,526 & 0.93 & $\begin{array}{l}0.88 \\
0.98\end{array}$ & 50.1 & $\begin{array}{l}8.24 \mathrm{E}- \\
03\end{array}$ \\
\hline L-HDL-cholesterol & 38,555 & 1,780 & 0.89 & $\begin{array}{l}0.84 \\
0.94\end{array}$ & 63 & $\begin{array}{l}2.13 \mathrm{E}- \\
05\end{array}$ & 38,488 & 1,775 & 0.92 & $\begin{array}{l}0.88 \\
0.98\end{array}$ & 66.6 & $\begin{array}{l}5.50 \mathrm{E}- \\
03\end{array}$ \\
\hline $\begin{array}{l}\text { L-HDL-cholesterol } \\
\text { esters }\end{array}$ & 35,101 & 1,529 & 0.90 & $\begin{array}{l}0.84 \\
0.95\end{array}$ & 69.1 & $\begin{array}{l}2.03 \mathrm{E}- \\
04\end{array}$ & 35,046 & 1,526 & 0.93 & $\begin{array}{l}0.88 \\
0.99\end{array}$ & 72.4 & $\begin{array}{l}1.37 \mathrm{E}- \\
02\end{array}$ \\
\hline L-HDL-free cholesterol & 35,101 & 1,529 & 0.89 & $\begin{array}{l}0.84 \\
0.94\end{array}$ & 67.6 & $\begin{array}{l}1.25 \mathrm{E}- \\
04\end{array}$ & 35,046 & 1,526 & 0.92 & $\begin{array}{l}0.87 \\
0.98\end{array}$ & 70.8 & $\begin{array}{l}9.96 \mathrm{E}- \\
03\end{array}$ \\
\hline L-HDL-total lipids & 35,101 & 1,529 & 0.90 & $\begin{array}{l}0.85 \\
0.95\end{array}$ & 69 & $\begin{array}{l}2.12 \mathrm{E}- \\
04\end{array}$ & 35,046 & 1,526 & 0.93 & $\begin{array}{l}0.88 \\
0.99\end{array}$ & 71.8 & $\begin{array}{l}1.70 \mathrm{E}- \\
02\end{array}$ \\
\hline L-HDL-phospholipids & 35,101 & 1,529 & 0.90 & $\begin{array}{l}0.85 \\
0.96\end{array}$ & 71.1 & $\begin{array}{l}6.29 \mathrm{E}- \\
04\end{array}$ & 35,046 & 1,526 & 0.94 & $\begin{array}{l}0.89 \\
1.00\end{array}$ & 72.2 & $\begin{array}{l}3.49 \mathrm{E}- \\
02\end{array}$ \\
\hline L-HDL concentration & 35,101 & 1,529 & 0.90 & $\begin{array}{l}0.85 \\
0.96\end{array}$ & 69.4 & $\begin{array}{l}8.53 \mathrm{E}- \\
04\end{array}$ & 35,046 & 1,526 & 0.94 & $\begin{array}{l}0.89 \\
1.00\end{array}$ & 71.2 & $\begin{array}{l}4.21 \mathrm{E}- \\
02\end{array}$ \\
\hline XL-HDL-free cholesterol & 35,099 & 1,527 & 0.91 & $\begin{array}{l}0.86 \\
0.96\end{array}$ & 0 & $\begin{array}{l}8.31 \mathrm{E}- \\
04\end{array}$ & 35,044 & 1,524 & 0.94 & $\begin{array}{l}0.89 \\
1.00\end{array}$ & 11.7 & $\begin{array}{l}3.55 \mathrm{E}- \\
02\end{array}$ \\
\hline S-LDL-triglycerides & 35,107 & 1,529 & 1.10 & $\begin{array}{l}1.05 \\
1.16\end{array}$ & 44.6 & $\begin{array}{l}1.97 \mathrm{E}- \\
04\end{array}$ & 35,052 & 1,526 & 1.07 & $\begin{array}{l}1.01 \\
1.12\end{array}$ & 51.3 & $\begin{array}{l}1.58 \mathrm{E}- \\
02\end{array}$ \\
\hline
\end{tabular}


Table 2 Results of Association Analysis Showing the Significant Metabolite Associations With Overall Incident Stroke (continued)

\begin{tabular}{|c|c|c|c|c|c|c|c|c|c|c|c|c|}
\hline \multirow[b]{2}{*}{ Metabolite } & \multicolumn{6}{|c|}{ Model 1} & \multicolumn{6}{|c|}{ Model 2} \\
\hline & No. & $\begin{array}{l}\text { No. } \\
\text { Cases }\end{array}$ & HR & $\mathrm{Cl}$ & $I^{2 \mathrm{~b}}$ & $p$ Value & No. & $\begin{array}{l}\text { No. } \\
\text { Cases }\end{array}$ & HR & $\mathrm{Cl}$ & $I^{2}$ & $p$ Value \\
\hline L-LDL-triglycerides $^{a}$ & 35,107 & 1,529 & 1.12 & $\begin{array}{l}1.06 \\
1.17\end{array}$ & 12.2 & $\begin{array}{l}3.00 \mathrm{E}- \\
05\end{array}$ & 35,052 & 1,526 & 1.09 & $\begin{array}{l}1.03 \\
1.14\end{array}$ & 27.5 & $\begin{array}{l}1.67 \mathrm{E}- \\
03\end{array}$ \\
\hline M-LDL-triglycerides ${ }^{a}$ & 35,106 & 1,529 & 1.12 & $\begin{array}{l}1.06 \\
1.18\end{array}$ & 0 & $\begin{array}{l}1.68 \mathrm{E}- \\
05\end{array}$ & 35,051 & 1,526 & 1.09 & $\begin{array}{l}1.03 \\
1.14\end{array}$ & 1.4 & $\begin{array}{l}1.19 \mathrm{E}- \\
03\end{array}$ \\
\hline XL-VLDL-triglycerides & 38,284 & 1,769 & 1.09 & $\begin{array}{l}1.04 \\
1.14\end{array}$ & 75.9 & $\begin{array}{l}1.56 \mathrm{E}- \\
04\end{array}$ & 38,217 & 1,764 & 1.05 & $\begin{array}{l}1.00 \\
1.10\end{array}$ & 73.9 & $\begin{array}{l}4.66 \mathrm{E}- \\
02\end{array}$ \\
\hline
\end{tabular}

Abbreviations: ApoA1 = apolipoprotein A1; Cl = confidence interval; $\mathrm{HDL}=$ high-density lipoprotein; $\mathrm{HR}=$ hazard ratio; IDL = intermediate-density lipoprotein; $I^{2}=$ heterogeneity parameter; $\mathrm{L}=$ large; $\mathrm{LDL}=$ low-density lipoprotein; $\mathrm{M}=$ medium; $p=p$ value for association of $\mathrm{metabolite}$ and stroke; $\mathrm{S}=\mathrm{small} ; \mathrm{VLDL}=$ verylow-density lipoprotein; $\mathrm{XL}=$ very large.

Model 1 adjusted for age, sex, body mass index, lipid-lowering medication, and study-specific covariates if needed. Model 2 additionally adjusted for smoking status, diabetes, and hypertension.

${ }^{\text {a }}$ Associations that surpassed significance threshold in model 2.

${ }^{\mathrm{b}}$ Random-effect meta-analysis was performed in the case of statistical heterogeneity, defined as $l^{2}>50 \%$. Subsequently, the correlation between effect estimates (HR) derived from fixed-and random-effect meta-analysis was checked. The correlation coefficient between these 2 estimates was 0.99.

\section{Discussion}

In this study, we identified 10 metabolites associated with the risk of stroke. These include amino acid histidine and cholesterol in HDL2, which were associated with decreased risk of stroke overall and ischemic stroke subtype, and glycolysisrelated metabolite pyruvate and acute-phase reaction markers glycoprotein acetyls, which were associated with increased risk of stroke overall and ischemic stroke. Cholesterol in medium HDL and triglycerides in medium and large LDL particles were associated with stroke overall, while amino acid phenylalanine and HDL subfractions, including cholesterol and free cholesterol in large HDL, were associated with ischemic but not with hemorrhagic stroke. This pattern of results was independent of traditional risk factors, including hypertension, diabetes, smoking, and BMI.

The strongest association was found between amino acid histidine and risk of stroke. We observed that a 1-SD increase in concentration of histidine was associated with $10 \%$ lower risk of stroke. The effect was similar across studies, with only the FINRISK97 study showing no effect. Even though the same direction of effect was observed for both ischemic and hemorrhagic stroke subtypes, the association was driven mainly by ischemic stroke. Histidine is a semiessential amino acid; adults generally produce it while children may not. Histidine can be converted to histamine, which shows a strong effect on vasodilatation and functions as a neurotransmitter in the brain. ${ }^{29,30}$ Previous studies reported that oral administration of histidine can reduce blood pressure. ${ }^{31-33}$ Plasma concentrations of histidine have been inversely associated with inflammation and oxidative stress in patients with chronic kidney disease and obese women with metabolic syndrome. ${ }^{34,35}$ Recent animal studies reported that histidine treatment alleviated the infarction induced by middle cerebral artery occlusion ${ }^{36}$ and showed long-term neuroprotection after cerebral ischemia with decreased infarct volume and improved neurologic function. ${ }^{37}$ Even though our findings support the results of previous studies, in the most comprehensive study of stroke to date within the China Kadoorie Biobank, histidine was not associated with ischemic or hemorrhagic stroke. However, in that study, a nominal association was found with myocardial infarction. ${ }^{11}$ This might be explained by either environmental or ethnic differences of studied populations or differences in the confounders for which the investigators adjusted. In the present study, we adjusted for a more comprehensive set of potential confounders, including BMI, lipid-lowering medication, diabetes, and hypertension.

We also found the glycolysis-related metabolite pyruvate to be associated with increased risk of stroke. The analyses of stroke subtypes suggested that this association was driven by ischemic incident stroke events. Our findings suggested that a 1-SD increase in pyruvate concentration was associated with $13 \%$ higher risk of ischemic stroke. Pyruvate is the end-product of glycolysis, and it is critical for supplying energy to the cell..$^{38}$ Pyruvate has previously been shown to protect against experimental stroke possibly by blocking inflammation..$^{39,40}$ In this light, our finding seems to contrast previously described effects of pyruvate. However, in a combined study of myocardial infarction and stroke using the same metabolomics platform as the present study, higher levels of pyruvate were also associated with a higher risk of cardiovascular disease. ${ }^{41}$ The mechanisms linking circulating levels of pyruvate to stroke and cardiovascular disease risk are still to be elucidated.

Acute-phase marker glycoprotein acetyls, mainly $\alpha-1$ glycoprotein, were associated with higher risk of stroke. Our analyses suggested that the association was strongest for the ischemic subtype, for which we found that an increase of $1 \mathrm{SD}$ in the circulating compound was associated with $13 \%$ higher risk of ischemic stroke. Our results confirmed the association of glycoprotein acetyl with ischemic stroke that was observed 


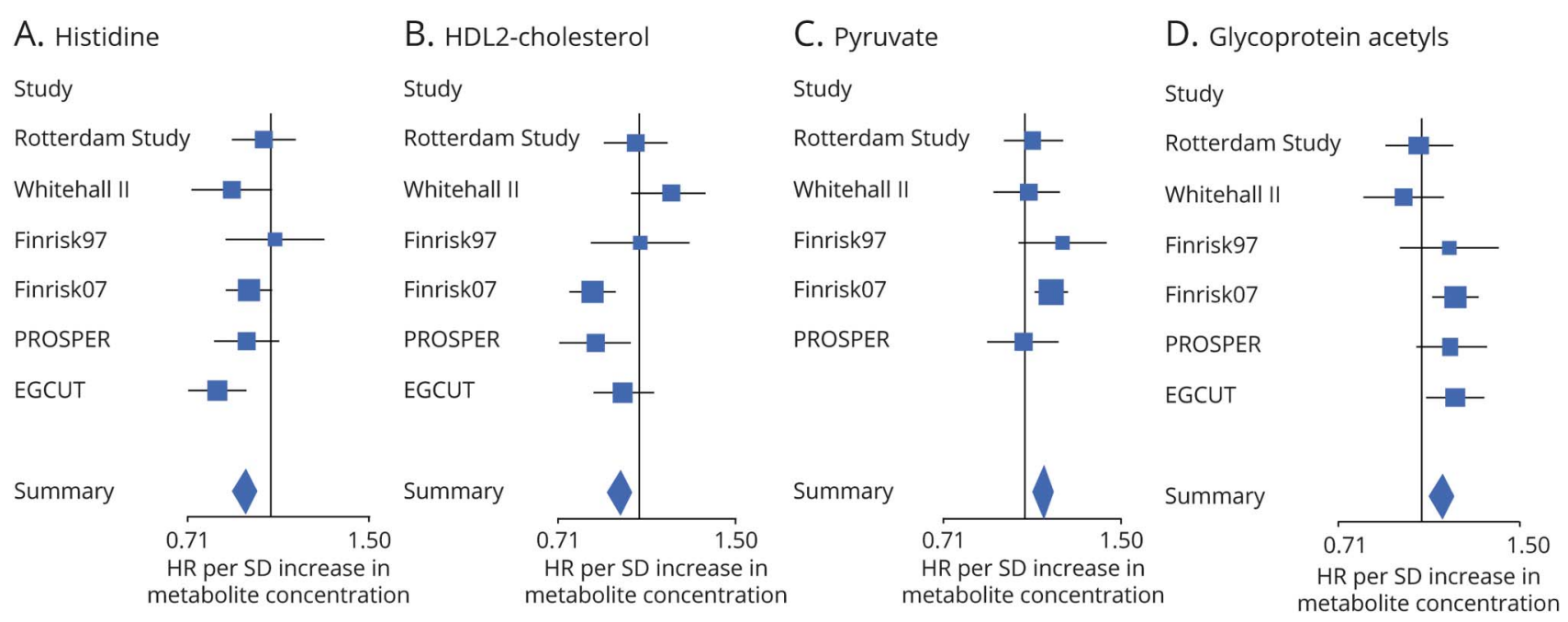

E. M-HDL-cholesterol

Study

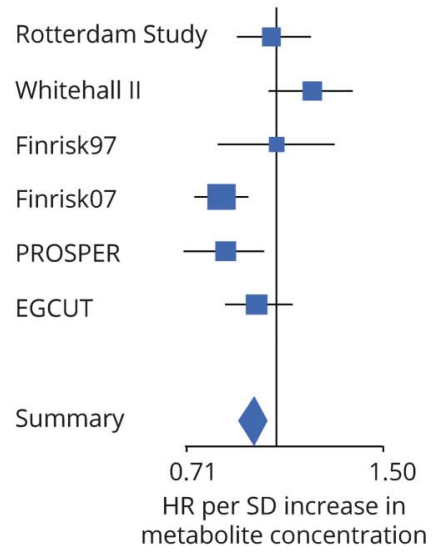

F. L-LDL-triglycerides

Study

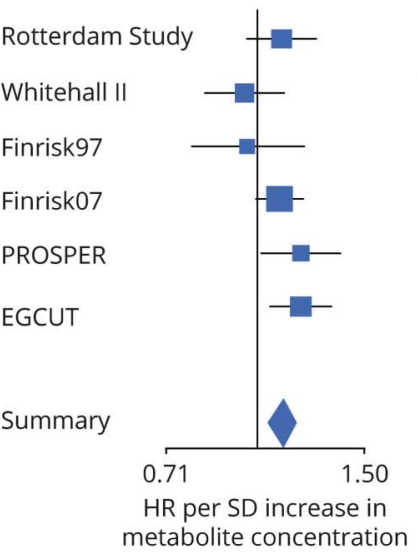

G. M-LDL-triglycerides

Study

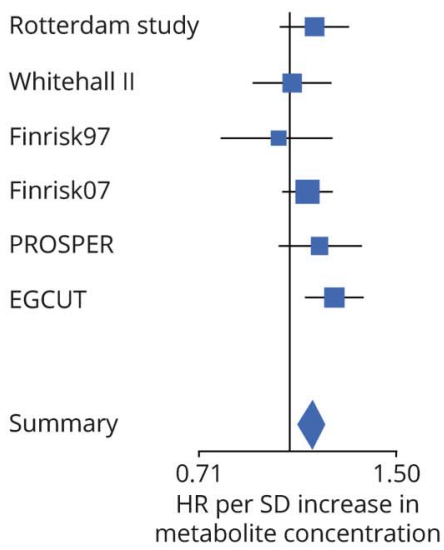

(A-G) Associations were significant after adjustment for age, sex, body mass index, lipid-lowering medication, smoking status, diabetes, and hypertension. EGCUT = Estonian biobank; FINRISK97 = FINRISK study 1997; HDL = high-density lipoprotein; L = large; HR = hazard ratio; LDL = low-density lipoprotein; M = medium; PROSPER = Prospective Study of Pravastatin in the Elderly at Risk.

in individuals in the China Kadoorie Biobank. ${ }^{11}$ Circulating levels of glycoprotein acetyls have previously been associated with cardiovascular diseases and dementia but also inflammatory disease, cancer, and mortality. ${ }^{41-43}$

Analyses focused on stroke subtypes revealed the association of essential amino acid phenylalanine with increased risk of ischemic stroke. A 1-SD increase in concentration of phenylalanine was associated with $12 \%$ higher risk of ischemic stroke. Phenylalanine is a precursor for tyrosine and catecholamines, including dopamine, epinephrine, and norepinephrine. Phenylalanine has previously been associated with increased risk of cardiovascular disease and diabetes. ${ }^{41,44,45}$ However, the association with phenylalanine remained after adjustment for diabetes. Phenylalanine was not associated with risk of hemorrhagic stroke.

The majority of circulating biomarkers measured by NMR metabolomics technology belong to lipid concentrations and the composition of 14 lipoprotein subparticles. This provides an excellent opportunity for a comprehensive investigation of lipoprotein particles in stroke because analyses of cholesterol and cholesterol subfractions have shown inconsistent results. ${ }^{3-5}$ Previous metabolomic and lipidomic studies of stroke reported associations of various molecular species with ischemic stroke, including ceramides, diacylglycerol, docosatrienoic acid, hydroxyeicosatetraenoic acid, hydroxyoctadecadienoic acid, lysophosphatidylcholines, and triacylglycerols. ${ }^{46}$ Furthermore, lipidomics approach provided insights into the metabolism of stroke induced by small vessel disease because associations with glucosylceramide, phosphatidylethanolamine, free fatty acid, and triacylglycerol were observed. ${ }^{47}$ In our study population, we observed associations of cholesterol in medium HDL with decreased risk of stroke and of triglycerides in large and medium LDL particles with increased risk of stroke. None of these lipoprotein measurements were found to be associated with stroke in the China Kadoorie Biobank. ${ }^{11}$ However, the 
Table 3 Associations for Incident Stroke Events When Classified by Stroke Type

\begin{tabular}{|c|c|c|c|c|c|c|c|c|c|c|c|}
\hline \multirow[b]{2}{*}{ Metabolite } & \multirow[b]{2}{*}{ Type } & \multicolumn{5}{|c|}{ Model 1} & \multicolumn{5}{|c|}{ Model 2} \\
\hline & & No. & $\begin{array}{l}\text { No. } \\
\text { Cases }\end{array}$ & HR & $\mathrm{Cl}$ & $p$ Value & No. & $\begin{array}{l}\text { No. } \\
\text { Cases }\end{array}$ & HR & $\mathrm{Cl}$ & $p$ Value \\
\hline Phenylalanine & $\begin{array}{l}\text { Hemorrhagic } \\
\text { Ischemic }^{a}\end{array}$ & $\begin{array}{l}30,144 \\
30,290\end{array}$ & $\begin{array}{l}214 \\
1,051\end{array}$ & $\begin{array}{l}0.94 \\
1.16\end{array}$ & $\begin{array}{l}0.81,1.09 \\
1.09,1.23\end{array}$ & $\begin{array}{l}3.90 \mathrm{E}-01 \\
3.15 \mathrm{E}- \\
06^{\mathrm{b}}\end{array}$ & $\begin{array}{l}30,092 \\
30,236\end{array}$ & $\begin{array}{l}214 \\
1,049\end{array}$ & $\begin{array}{l}0.91 \\
1.12\end{array}$ & $\begin{array}{l}0.78,1.05 \\
1.05,1.19\end{array}$ & $\begin{array}{l}2.00 \mathrm{E}-01 \\
4.13 \mathrm{E}- \\
04^{\mathrm{b}}\end{array}$ \\
\hline Histidine & $\begin{array}{l}\text { Hemorrhagic } \\
\text { Ischemic }^{a}\end{array}$ & $\begin{array}{l}30,070 \\
30,216\end{array}$ & $\begin{array}{l}214 \\
1,050\end{array}$ & $\begin{array}{l}0.95 \\
0.88\end{array}$ & $\begin{array}{l}0.82,1.1 \\
0.82,0.94\end{array}$ & $\begin{array}{l}4.78 \mathrm{E}-01 \\
1.18 \mathrm{E}- \\
04^{\mathrm{b}}\end{array}$ & $\begin{array}{l}30,018 \\
30,162\end{array}$ & $\begin{array}{l}214 \\
1,048\end{array}$ & $\begin{array}{l}0.96 \\
0.89\end{array}$ & $\begin{array}{l}0.83,1.11 \\
0.84,0.95\end{array}$ & $\begin{array}{l}6.16 \mathrm{E}-01 \\
4.94 \mathrm{E}- \\
04^{\mathrm{b}}\end{array}$ \\
\hline ApoA1 & $\begin{array}{l}\text { Hemorrhagic } \\
\text { Ischemic }\end{array}$ & $\begin{array}{l}30,155 \\
30,301\end{array}$ & $\begin{array}{l}216 \\
1,051\end{array}$ & $\begin{array}{l}1.03 \\
0.89\end{array}$ & $\begin{array}{l}0.89,1.19 \\
0.83,0.95\end{array}$ & $\begin{array}{l}7.32 \mathrm{E}-01 \\
5.87 \mathrm{E}- \\
04^{\mathrm{b}}\end{array}$ & $\begin{array}{l}30,103 \\
30,247\end{array}$ & $\begin{array}{l}216 \\
1,049\end{array}$ & $\begin{array}{l}1.04 \\
0.92\end{array}$ & $\begin{array}{l}0.9,1.2 \\
0.86,0.98\end{array}$ & $\begin{array}{l}\text { 6.17E-01 } \\
1.43 \mathrm{E}-02\end{array}$ \\
\hline HDL-cholesterol & $\begin{array}{l}\text { Hemorrhagic } \\
\text { Ischemic }\end{array}$ & $\begin{array}{l}30,155 \\
30,301\end{array}$ & $\begin{array}{l}216 \\
1,051\end{array}$ & $\begin{array}{l}1.04 \\
0.86\end{array}$ & $\begin{array}{l}0.9,1.21 \\
0.81,0.92\end{array}$ & $\begin{array}{l}5.63 \mathrm{E}-01 \\
1.82 \mathrm{E}- \\
05^{\mathrm{b}}\end{array}$ & $\begin{array}{l}30,103 \\
30,247\end{array}$ & $\begin{array}{l}216 \\
1,049\end{array}$ & $\begin{array}{l}1.07 \\
0.9\end{array}$ & $\begin{array}{l}0.92,1.24 \\
0.84,0.96\end{array}$ & $\begin{array}{l}3.97 \mathrm{E}-01 \\
1.89 \mathrm{E}-03\end{array}$ \\
\hline HDL2-cholesterol & $\begin{array}{l}\text { Hemorrhagic } \\
\text { Ischemic }^{\mathrm{a}}\end{array}$ & $\begin{array}{l}30,155 \\
30,301\end{array}$ & $\begin{array}{l}216 \\
1,051\end{array}$ & $\begin{array}{l}1.04 \\
0.85\end{array}$ & $\begin{array}{l}0.9,1.21 \\
0.8,0.91\end{array}$ & $\begin{array}{l}5.75 \mathrm{E}-01 \\
2.85 \mathrm{E}- \\
06^{\mathrm{b}}\end{array}$ & $\begin{array}{l}30,103 \\
30,247\end{array}$ & $\begin{array}{l}216 \\
1,049\end{array}$ & $\begin{array}{l}1.07 \\
0.89\end{array}$ & $\begin{array}{l}0.92,1.24 \\
0.83,0.95\end{array}$ & $\begin{array}{l}3.90 \mathrm{E}-01 \\
5.29 \mathrm{E}- \\
04^{\mathrm{b}}\end{array}$ \\
\hline IDL-triglycerides & $\begin{array}{l}\text { Hemorrhagic } \\
\text { Ischemic }\end{array}$ & $\begin{array}{l}33,609 \\
33,755\end{array}$ & $\begin{array}{l}246 \\
1,270\end{array}$ & $\begin{array}{l}0.92 \\
1.13\end{array}$ & $\begin{array}{l}0.81,1.06 \\
1.07,1.2\end{array}$ & $\begin{array}{l}2.63 \mathrm{E}-01 \\
6.91 \mathrm{E}- \\
06^{\mathrm{b}}\end{array}$ & $\begin{array}{l}33,545 \\
33,689\end{array}$ & $\begin{array}{l}246 \\
1,266\end{array}$ & $\begin{array}{l}0.89 \\
1.09\end{array}$ & $\begin{array}{l}0.78,1.02 \\
1.03,1.15\end{array}$ & $\begin{array}{l}1.02 \mathrm{E}-01 \\
2.01 \mathrm{E}-03\end{array}$ \\
\hline LDL-triglycerides & $\begin{array}{l}\text { Hemorrhagic } \\
\text { Ischemic }\end{array}$ & $\begin{array}{l}30,155 \\
30,301\end{array}$ & $\begin{array}{l}216 \\
1,051\end{array}$ & $\begin{array}{l}1.02 \\
1.14\end{array}$ & $\begin{array}{l}0.88,1.18 \\
1.07,1.21\end{array}$ & $\begin{array}{l}8.27 \mathrm{E}-01 \\
2.89 \mathrm{E}- \\
05^{\mathrm{b}}\end{array}$ & $\begin{array}{l}30,103 \\
30,247\end{array}$ & $\begin{array}{l}216 \\
1,049\end{array}$ & $\begin{array}{l}0.99 \\
1.1\end{array}$ & $\begin{array}{l}0.85,1.14 \\
1.04,1.17\end{array}$ & $\begin{array}{l}8.62 \mathrm{E}-01 \\
1.82 \mathrm{E}-03\end{array}$ \\
\hline Glucose & $\begin{array}{l}\text { Hemorrhagic } \\
\text { Ischemic }\end{array}$ & $\begin{array}{l}30,033 \\
30,179\end{array}$ & $\begin{array}{l}214 \\
1,048\end{array}$ & $\begin{array}{l}1.13 \\
1.17\end{array}$ & $\begin{array}{l}0.99,1.28 \\
1.12,1.23\end{array}$ & $\begin{array}{l}7.07 \mathrm{E}-02 \\
5.37 \mathrm{E}- \\
11^{\mathrm{b}}\end{array}$ & $\begin{array}{l}29,981 \\
30,125\end{array}$ & $\begin{array}{l}214 \\
1,046\end{array}$ & $\begin{array}{l}1.09 \\
1.07\end{array}$ & $\begin{array}{l}0.96,1.24 \\
1.01,1.13\end{array}$ & $\begin{array}{l}2.20 \mathrm{E}-01 \\
2.13 \mathrm{E}-02\end{array}$ \\
\hline Lactate & $\begin{array}{l}\text { Hemorrhagic } \\
\text { Ischemic }\end{array}$ & $\begin{array}{l}30,153 \\
30,299\end{array}$ & $\begin{array}{l}216 \\
1,051\end{array}$ & $\begin{array}{l}1.06 \\
1.16\end{array}$ & $\begin{array}{l}0.92,1.22 \\
1.09,1.24\end{array}$ & $\begin{array}{l}4.04 \mathrm{E}-01 \\
1.11 \mathrm{E}- \\
06^{\mathrm{b}}\end{array}$ & $\begin{array}{l}30,101 \\
30,245\end{array}$ & $\begin{array}{l}216 \\
1,049\end{array}$ & $\begin{array}{l}1.04 \\
1.1\end{array}$ & $\begin{array}{l}0.9,1.19 \\
1.04,1.17\end{array}$ & $\begin{array}{l}6.13 \mathrm{E}-01 \\
1.98 \mathrm{E}-03\end{array}$ \\
\hline Pyruvate & $\begin{array}{l}\text { Hemorrhagic } \\
\text { Ischemic }^{a}\end{array}$ & $\begin{array}{l}19,481 \\
19,627\end{array}$ & $\begin{array}{l}167 \\
778\end{array}$ & $\begin{array}{l}0.99 \\
1.17\end{array}$ & $\begin{array}{l}0.84,1.16 \\
1.11,1.23\end{array}$ & $\begin{array}{l}8.70 \mathrm{E}-01 \\
2.86 \mathrm{E}- \\
10^{\mathrm{b}}\end{array}$ & $\begin{array}{l}19,429 \\
19,573\end{array}$ & $\begin{array}{l}167 \\
776\end{array}$ & $\begin{array}{l}0.96 \\
1.13\end{array}$ & $\begin{array}{l}0.81,1.12 \\
1.07,1.19\end{array}$ & $\begin{array}{l}5.94 \mathrm{E}-01 \\
1.93 \mathrm{E}- \\
05^{\mathrm{b}}\end{array}$ \\
\hline Glycoprotein acetyls & $\begin{array}{l}\text { Hemorrhagic } \\
\text { Ischemic }^{\mathrm{a}}\end{array}$ & $\begin{array}{l}30,154 \\
30,300\end{array}$ & $\begin{array}{l}216 \\
1,051\end{array}$ & $\begin{array}{l}1.02 \\
1.2\end{array}$ & $\begin{array}{l}0.88,1.18 \\
1.13,1.28\end{array}$ & $\begin{array}{l}8.06 \mathrm{E}-01 \\
8.55 \mathrm{E}- \\
09^{\mathrm{b}}\end{array}$ & $\begin{array}{l}30,102 \\
30,246\end{array}$ & $\begin{array}{l}216 \\
1,049\end{array}$ & $\begin{array}{l}0.96 \\
1.13\end{array}$ & $\begin{array}{l}0.83,1.11 \\
1.06,1.2\end{array}$ & $\begin{array}{l}6.28 \mathrm{E}-01 \\
2.17 \mathrm{E}- \\
04^{\mathrm{b}}\end{array}$ \\
\hline $\begin{array}{l}\text { Mean diameter of } \\
\text { HDL }\end{array}$ & $\begin{array}{l}\text { Hemorrhagic } \\
\text { Ischemic }\end{array}$ & $\begin{array}{l}30,155 \\
30,301\end{array}$ & $\begin{array}{l}216 \\
1,051\end{array}$ & $\begin{array}{l}1.03 \\
0.86\end{array}$ & $\begin{array}{l}0.89,1.2 \\
0.8,0.92\end{array}$ & $\begin{array}{l}6.98 \mathrm{E}-01 \\
1.28 \mathrm{E}- \\
05^{\mathrm{b}}\end{array}$ & $\begin{array}{l}30,103 \\
30,247\end{array}$ & $\begin{array}{l}216 \\
1,049\end{array}$ & $\begin{array}{l}1.07 \\
0.9\end{array}$ & $\begin{array}{l}0.92,1.24 \\
0.84,0.96\end{array}$ & $\begin{array}{l}4.08 \mathrm{E}-01 \\
2.93 \mathrm{E}-03\end{array}$ \\
\hline S-HDL-triglycerides & $\begin{array}{l}\text { Hemorrhagic } \\
\text { Ischemic }\end{array}$ & $\begin{array}{l}30,156 \\
30,302\end{array}$ & $\begin{array}{l}216 \\
1,051\end{array}$ & $\begin{array}{l}1 \\
1.14\end{array}$ & $\begin{array}{l}0.86,1.15 \\
1.08,1.22\end{array}$ & $\begin{array}{l}9.71 \mathrm{E}-01 \\
1.99 \mathrm{E}- \\
05^{\mathrm{b}}\end{array}$ & $\begin{array}{l}30,104 \\
30,248\end{array}$ & $\begin{array}{l}216 \\
1,049\end{array}$ & $\begin{array}{l}0.96 \\
1.09\end{array}$ & $\begin{array}{l}0.83,1.11 \\
1.02,1.16\end{array}$ & $\begin{array}{l}5.84 \mathrm{E}-01 \\
8.32 \mathrm{E}-03\end{array}$ \\
\hline M-HDL-cholesterol & $\begin{array}{l}\text { Hemorrhagic } \\
\text { Ischemic }\end{array}$ & $\begin{array}{l}33,608 \\
33,754\end{array}$ & $\begin{array}{l}246 \\
1,270\end{array}$ & $\begin{array}{l}1 \\
0.88\end{array}$ & $\begin{array}{l}0.87,1.15 \\
0.83,0.93\end{array}$ & $\begin{array}{l}9.88 \mathrm{E}-01 \\
3.11 \mathrm{E}- \\
05^{\mathrm{b}}\end{array}$ & $\begin{array}{l}33,544 \\
33,688\end{array}$ & $\begin{array}{l}246 \\
1,266\end{array}$ & $\begin{array}{l}1.02 \\
0.91\end{array}$ & $\begin{array}{l}0.88,1.17 \\
0.85,0.97\end{array}$ & $\begin{array}{l}8.27 \mathrm{E}-01 \\
1.95 \mathrm{E}-03\end{array}$ \\
\hline $\begin{array}{l}\text { M-HDL-cholesterol } \\
\text { esters }\end{array}$ & $\begin{array}{l}\text { Hemorrhagic } \\
\text { Ischemic }\end{array}$ & $\begin{array}{l}30,154 \\
30,300\end{array}$ & $\begin{array}{l}216 \\
1,051\end{array}$ & $\begin{array}{l}0.99 \\
0.89\end{array}$ & $\begin{array}{l}0.86,1.14 \\
0.83,0.95\end{array}$ & $\begin{array}{l}8.84 \mathrm{E}-01 \\
4.60 \mathrm{E}- \\
04^{\mathrm{b}}\end{array}$ & $\begin{array}{l}30,102 \\
30,246\end{array}$ & $\begin{array}{l}216 \\
1,049\end{array}$ & $\begin{array}{l}1 \\
0.91\end{array}$ & $\begin{array}{l}0.87,1.16 \\
0.86,0.98\end{array}$ & $\begin{array}{l}9.72 \mathrm{E}-01 \\
6.99 \mathrm{E}-03\end{array}$ \\
\hline $\begin{array}{l}\text { M-HDL-free } \\
\text { cholesterol }\end{array}$ & $\begin{array}{l}\text { Hemorrhagic } \\
\text { Ischemic }\end{array}$ & $\begin{array}{l}30,154 \\
30,300\end{array}$ & $\begin{array}{l}216 \\
1,051\end{array}$ & $\begin{array}{l}1.02 \\
0.9\end{array}$ & $\begin{array}{l}0.88,1.18 \\
0.84,0.96\end{array}$ & $\begin{array}{l}8.25 \mathrm{E}-01 \\
1.75 \mathrm{E}-03\end{array}$ & $\begin{array}{l}30,102 \\
30,246\end{array}$ & $\begin{array}{l}216 \\
1,049\end{array}$ & $\begin{array}{l}1.02 \\
0.92\end{array}$ & $\begin{array}{l}0.88,1.18 \\
0.86,0.98\end{array}$ & $\begin{array}{l}\text { 7.79E-01 } \\
1.56 \mathrm{E}-02\end{array}$ \\
\hline L-HDL-cholesterol & $\begin{array}{l}\text { Hemorrhagic } \\
\text { Ischemic }^{a}\end{array}$ & $\begin{array}{l}33,603 \\
33,749\end{array}$ & $\begin{array}{l}246 \\
1,270\end{array}$ & $\begin{array}{l}1.07 \\
0.85\end{array}$ & $\begin{array}{l}0.93,1.24 \\
0.8,0.91\end{array}$ & $\begin{array}{l}3.19 \mathrm{E}-01 \\
2.03 \mathrm{E}- \\
06^{\mathrm{b}}\end{array}$ & $\begin{array}{l}33,539 \\
33,683\end{array}$ & $\begin{array}{l}246 \\
1,266\end{array}$ & $\begin{array}{l}1.11 \\
0.89\end{array}$ & $\begin{array}{l}0.96,1.28 \\
0.84,0.95\end{array}$ & $\begin{array}{l}1.56 \mathrm{E}-01 \\
9.00 \mathrm{E}- \\
04^{\mathrm{b}}\end{array}$ \\
\hline $\begin{array}{l}\text { L-HDL-cholesterol } \\
\text { esters }\end{array}$ & $\begin{array}{l}\text { Hemorrhagic } \\
\text { Ischemic }\end{array}$ & $\begin{array}{l}30,149 \\
30,295\end{array}$ & $\begin{array}{l}216 \\
1,051\end{array}$ & $\begin{array}{l}1.07 \\
0.86\end{array}$ & $\begin{array}{l}0.92,1.24 \\
0.8,0.92\end{array}$ & $\begin{array}{l}3.88 \mathrm{E}-01 \\
4.28 \mathrm{E}- \\
05^{\mathrm{b}}\end{array}$ & $\begin{array}{l}30,097 \\
30,241\end{array}$ & $\begin{array}{l}216 \\
1,049\end{array}$ & $\begin{array}{l}1.1 \\
0.9\end{array}$ & $\begin{array}{l}0.95,1.28 \\
0.84,0.97\end{array}$ & $\begin{array}{l}2.13 \mathrm{E}-01 \\
3.59 \mathrm{E}-03\end{array}$ \\
\hline
\end{tabular}


Table 3 Associations for Incident Stroke Events When Classified by Stroke Type (continued)

\begin{tabular}{|c|c|c|c|c|c|c|c|c|c|c|c|}
\hline \multirow[b]{2}{*}{ Metabolite } & \multirow[b]{2}{*}{ Type } & \multicolumn{5}{|c|}{ Model 1} & \multicolumn{5}{|c|}{ Model 2} \\
\hline & & No. & $\begin{array}{l}\text { No. } \\
\text { Cases }\end{array}$ & HR & $\mathrm{Cl}$ & $p$ Value & No. & $\begin{array}{l}\text { No. } \\
\text { Cases }\end{array}$ & HR & $\mathrm{Cl}$ & $p$ Value \\
\hline $\begin{array}{l}\text { L-HDL-free } \\
\text { cholesterol }\end{array}$ & $\begin{array}{l}\text { Hemorrhagic } \\
\text { Ischemic }^{a}\end{array}$ & $\begin{array}{l}30,149 \\
30,295\end{array}$ & $\begin{array}{l}216 \\
1,051\end{array}$ & $\begin{array}{l}1.09 \\
0.85\end{array}$ & $\begin{array}{l}0.93,1.26 \\
0.79,0.91\end{array}$ & $\begin{array}{l}2.81 \mathrm{E}-01 \\
1.04 \mathrm{E}- \\
05^{\mathrm{b}}\end{array}$ & $\begin{array}{l}30,097 \\
30,241\end{array}$ & $\begin{array}{l}216 \\
1,049\end{array}$ & $\begin{array}{l}1.12 \\
0.89\end{array}$ & $\begin{array}{l}0.96,1.3 \\
0.82,0.95\end{array}$ & $\begin{array}{l}1.44 \mathrm{E}-01 \\
1.33 \mathrm{E}- \\
03^{\mathrm{b}}\end{array}$ \\
\hline L-HDL-total lipids & $\begin{array}{l}\text { Hemorrhagic } \\
\text { Ischemic }\end{array}$ & $\begin{array}{l}30,149 \\
30,295\end{array}$ & $\begin{array}{l}216 \\
1,051\end{array}$ & $\begin{array}{l}1.06 \\
0.87\end{array}$ & $\begin{array}{l}0.91,1.23 \\
0.81,0.93\end{array}$ & $\begin{array}{l}4.71 \mathrm{E}-01 \\
5.91 \mathrm{E}- \\
05^{\mathrm{b}}\end{array}$ & $\begin{array}{l}30,097 \\
30,241\end{array}$ & $\begin{array}{l}216 \\
1,049\end{array}$ & $\begin{array}{l}1.09 \\
0.91\end{array}$ & $\begin{array}{l}0.93,1.27 \\
0.84,0.97\end{array}$ & $\begin{array}{l}2.77 \mathrm{E}-01 \\
6.00 \mathrm{E}-03\end{array}$ \\
\hline L-HDL-concentration & $\begin{array}{l}\text { Hemorrhagic } \\
\text { Ischemic }\end{array}$ & $\begin{array}{l}30,149 \\
30,295\end{array}$ & $\begin{array}{l}216 \\
1,051\end{array}$ & $\begin{array}{l}1.09 \\
0.87\end{array}$ & $\begin{array}{l}0.94,1.27 \\
0.81,0.93\end{array}$ & $\begin{array}{l}2.73 \mathrm{E}-01 \\
1.30 \mathrm{E}- \\
04^{\mathrm{b}}\end{array}$ & $\begin{array}{l}30,097 \\
30,241\end{array}$ & $\begin{array}{l}216 \\
1,049\end{array}$ & $\begin{array}{l}1.12 \\
0.91\end{array}$ & $\begin{array}{l}0.96,1.3 \\
0.85,0.98\end{array}$ & $\begin{array}{l}1.44 \mathrm{E}-01 \\
1.04 \mathrm{E}-02\end{array}$ \\
\hline L-HDL-phospholipids & $\begin{array}{l}\text { Hemorrhagic } \\
\text { Ischemic }\end{array}$ & $\begin{array}{l}30,149 \\
30,295\end{array}$ & $\begin{array}{l}216 \\
1,051\end{array}$ & $\begin{array}{l}1.08 \\
0.87\end{array}$ & $\begin{array}{l}0.93,1.26 \\
0.81,0.93\end{array}$ & $\begin{array}{l}3.21 \mathrm{E}-01 \\
9.62 \mathrm{E}- \\
05^{\mathrm{b}}\end{array}$ & $\begin{array}{l}30,097 \\
30,241\end{array}$ & $\begin{array}{l}216 \\
1,049\end{array}$ & $\begin{array}{l}1.11 \\
0.91\end{array}$ & $\begin{array}{l}0.95,1.29 \\
0.85,0.98\end{array}$ & $\begin{array}{l}1.85 \mathrm{E}-01 \\
9.32 \mathrm{E}-03\end{array}$ \\
\hline $\begin{array}{l}\text { XL-HDL-free } \\
\text { cholesterol }\end{array}$ & $\begin{array}{l}\text { Hemorrhagic } \\
\text { Ischemic }\end{array}$ & $\begin{array}{l}30,147 \\
30,293\end{array}$ & $\begin{array}{l}216 \\
1,049\end{array}$ & $\begin{array}{l}1.07 \\
0.88\end{array}$ & $\begin{array}{l}0.93,1.24 \\
0.82,0.94\end{array}$ & $\begin{array}{l}3.52 \mathrm{E}-01 \\
3.46 \mathrm{E}- \\
04^{\mathrm{b}}\end{array}$ & $\begin{array}{l}30,095 \\
30,239\end{array}$ & $\begin{array}{l}216 \\
1,047\end{array}$ & $\begin{array}{l}1.09 \\
0.92\end{array}$ & $\begin{array}{l}0.94,1.26 \\
0.86,0.99\end{array}$ & $\begin{array}{l}2.38 \mathrm{E}-01 \\
1.75 \mathrm{E}-02\end{array}$ \\
\hline S-LDL-triglycerides & $\begin{array}{l}\text { Hemorrhagic } \\
\text { Ischemic }\end{array}$ & $\begin{array}{l}30,155 \\
30,301\end{array}$ & $\begin{array}{l}216 \\
1,051\end{array}$ & $\begin{array}{l}1.00 \\
1.12\end{array}$ & $\begin{array}{l}0.87,1.16 \\
1.06,1.19\end{array}$ & $\begin{array}{l}9.84 \mathrm{E}-01 \\
1.18 \mathrm{E}- \\
04^{\mathrm{b}}\end{array}$ & $\begin{array}{l}30,103 \\
30,247\end{array}$ & $\begin{array}{l}216 \\
1,049\end{array}$ & $\begin{array}{l}0.97 \\
1.08\end{array}$ & $\begin{array}{l}0.84,1.12 \\
1.02,1.15\end{array}$ & $\begin{array}{l}6.99 \mathrm{E}-01 \\
1.10 \mathrm{E}-02\end{array}$ \\
\hline L-LDL-triglycerides & $\begin{array}{l}\text { Hemorrhagic } \\
\text { Ischemic }\end{array}$ & $\begin{array}{l}30,155 \\
30,301\end{array}$ & $\begin{array}{l}216 \\
1,051\end{array}$ & $\begin{array}{l}1.01 \\
1.13\end{array}$ & $\begin{array}{l}0.87,1.17 \\
1.07,1.2\end{array}$ & $\begin{array}{l}9.12 \mathrm{E}-01 \\
4.39 \mathrm{E}- \\
05^{\mathrm{b}}-\end{array}$ & $\begin{array}{l}30,103 \\
30,247\end{array}$ & $\begin{array}{l}216 \\
1,049\end{array}$ & $\begin{array}{l}0.98 \\
1.1\end{array}$ & $\begin{array}{l}0.85,1.13 \\
1.03,1.17\end{array}$ & $\begin{array}{l}\text { 7.87E-01 } \\
2.20 \mathrm{E}-03\end{array}$ \\
\hline M-LDL-triglycerides & $\begin{array}{l}\text { Hemorrhagic } \\
\text { Ischemic }\end{array}$ & $\begin{array}{l}30,154 \\
30,300\end{array}$ & $\begin{array}{l}216 \\
1,051\end{array}$ & $\begin{array}{l}1.04 \\
1.14\end{array}$ & $\begin{array}{l}0.9,1.2 \\
1.07,1.21\end{array}$ & $\begin{array}{l}5.70 \mathrm{E}-01 \\
2.84 \mathrm{E}- \\
05^{\mathrm{b}}\end{array}$ & $\begin{array}{l}30,102 \\
30,246\end{array}$ & $\begin{array}{l}216 \\
1,049\end{array}$ & $\begin{array}{l}1.02 \\
1.1\end{array}$ & $\begin{array}{l}0.88,1.17 \\
1.04,1.17\end{array}$ & $\begin{array}{l}8.35 \mathrm{E}-01 \\
1.80 \mathrm{E}-03\end{array}$ \\
\hline $\begin{array}{l}\text { XL-VLDL- } \\
\text { triglycerides }\end{array}$ & $\begin{array}{l}\text { Hemorrhagic } \\
\text { Ischemic }\end{array}$ & $\begin{array}{l}33,352 \\
33,499\end{array}$ & $\begin{array}{l}242 \\
1,263\end{array}$ & $\begin{array}{l}0.98 \\
1.12\end{array}$ & $\begin{array}{l}0.85,1.12 \\
1.06,1.18\end{array}$ & $\begin{array}{l}7.66 \mathrm{E}-01 \\
2.00 \mathrm{E}- \\
05^{\mathrm{b}}\end{array}$ & $\begin{array}{l}33,288 \\
33,433\end{array}$ & $\begin{array}{l}242 \\
1,259\end{array}$ & $\begin{array}{l}0.96 \\
1.07\end{array}$ & $\begin{array}{l}0.83,1.1 \\
1.01,1.13\end{array}$ & $\begin{array}{l}5.23 \mathrm{E}-01 \\
1.41 \mathrm{E}-02\end{array}$ \\
\hline
\end{tabular}

Abbreviations: ApoA1 = apolipoprotein A1; Cl = confidence interval; $\mathrm{HDL}=$ high-density lipoprotein; $\mathrm{HR}$ = hazard ratio; IDL = intermediate-density lipoprotein; $R^{2}=$ heterogeneity parameter; $\mathrm{LDL}=$ low-density lipoprotein; $\mathrm{M}=$ medium; $\mathrm{L}=$ large; $p=p$ value for association of metabolite and stroke; $\mathrm{S}=\mathrm{small} ; \mathrm{VLDL}=$ verylow-density lipoprotein; $\mathrm{XL}=$ very large.

Metabolites that showed significant association with overall incident stroke in table 2 were included.

Model 1 adjusted for age, sex, body mass index, lipid-lowering medication, and ethnicity if needed. Model 2 additionally adjusted for smoking status, diabetes, and hypertension.

${ }^{a}$ Associations that surpassed the significance threshold in model 2.

${ }^{\mathrm{b}}$ Associations that passed the threshold for multiple testing.

association of cholesterol in medium HDL with decreased risk of stroke was previously observed in the cohort of Japanese men and women. ${ }^{48}$ Furthermore, previous studies also showed inverse association of coronary heart disease with medium-sized HDL particles. ${ }^{49}$ Alterations in specific HDL particles provide additional evidence about the heterogeneity of HDL lipoprotein particles. However, mechanisms through which specific HDL particles might protect against stroke are not well understood yet. Previous studies reported that smaller HDL particles have a larger capacity to remove cholesterol from membranes of peripheral cells such as macrophage foam cell. ${ }^{48,50}$ This potentially antiatherogenic effect is one possible mechanism underlying association of medium HDL cholesterol and stroke. This is also in line with our finding that individuals with higher cholesterol levels in medium HDL particle subclasses may be protected against stroke. Another explanation for the HDL protective effect could be its antioxidant function, which differs across subfractions. Previous studies showed that antioxidant properties of HDL were enriched in the smallest and densest HDL particles, including medium HDL. ${ }^{51,52}$ Similarly, antiapoptotic and anti-inflammatory properties of HDL may also play a role in protection against stroke. Sphingosine-1phosphate and other lipids carried on HDL particles are possible molecular mediators of this anti-inflammatory effect. Previous studies reported enrichment of sphingosine-1-phosphate in small and dense HDL particles and its inverse correlation endothelial cell apoptosis. ${ }^{52,53}$ Furthermore, specific LDL particles such as triglycerides in large and medium LDL were associated with increased risk of stroke in our study. Previous studies reported high LDL triglycerides levels to be associated with incident stroke and coronary heart disease. ${ }^{54}$ Because higher LDL triglycerides levels were also reported to be associated with increased high-sensitivity C-reactive protein level and white blood cell count, one possible mechanism underlying association of LDL triglycerides and cerebrovascular disease may be inflammation. ${ }^{54,55}$ Interestingly, the China Kadoorie 
Biobank reported associations of very-low-density lipoprotein, intermediate-density lipoprotein, and LDL with ischemic stroke. ${ }^{11}$ However, we were not able to confirm these results in our study population. Lack of replication might be explained by environmental and ethnic differences of studied populations or the confounders that were adjusted for.

The strengths of our study include its large sample size, prospective study design with detailed data collection over a long period of follow-up, and the same experimental NMR setup for metabolite quantification across multiple studies. Our study also has several limitations. With new, improved methods available, many additional metabolites can be measured, which can be of importance for stroke. ${ }^{56}$ Included studies showed heterogeneity in terms of types of samples used across the cohorts and different times and types of sample storage. Even though different sample material was used in cohorts, a previously published article illustrated for NMR-based lipoprotein subclass measures that most metabolite levels are identical in plasma and serum samples, in particular lipid measures. ${ }^{57}$ For some metabolites, the absolute levels are slightly different with constant offset, but the relation is linear. This would suggest that metabolite variability in different types of samples is not problematic for cohort-specific analysis followed by meta-analysis, as illustrated in many published articles that have combined analyses of plasma and serum samples in meta-analysis ${ }^{5,59}$ and showed consistent results between the cohorts with different blood specimens. Furthermore, highly consistent epidemiologic results have been observed between studies that differ in terms of the time of sample storage. It is well known that storage slightly modifies the lipoprotein composition of serum/ plasma samples; however, these effects are due to biological changes in the actual samples and are not related to the analysis method as such. These are minor compared to interindividual differences in metabolite concentrations if the samples are handled according to standard clinical laboratory practices and stored at least in $-70^{\circ} \mathrm{C}$. Deelen et al. ${ }^{58}$ and van der Lee et al. ${ }^{25}$ reported biomarker association with mortality or cognition using the same population-based studies as in our project, and the metabolite associations showed consistency even though there were differences in how long the samples have been stored. There was also heterogeneity in the methods to ascertain cases of incident stroke across the cohorts. Most of the cohort studies used electronic health registries, which may have limited sensitivity and subsequently influenced power to identify novel significant associations. Statistical power was reduced in analyses of stroke subtypes because some of the cohorts were unable to distinguish between them. Limited sample size for the analysis of hemorrhagic stroke reduced our ability to detect novel associations for this stroke type. Finally, reported associations may represent signals due to other metabolites or other factors. Therefore, future studies should explore whether these metabolites play a causal role.

We found an association between 10 metabolites and risk of stroke in 1,791 incident stroke events observed among 38,797 individuals from 7 prospective cohort studies. The biological mechanisms underlying these associations should be the subject of further studies.

\section{Acknowledgment}

Rotterdam Study: The Rotterdam Study is supported by the Erasmus MC University Medical Center and Erasmus University Rotterdam; The Netherlands Organisation for Scientific Research; The Netherlands Organisation for Health Research and Development; the Research Institute for Diseases in the Elderly; The Netherlands Genomics Initiative; the Ministry of Education, Culture and Science; the Ministry of Health, Welfare and Sports; the European Commission; and the Municipality of Rotterdam. Metabolomics measurements were funded by Biobanking and Biomolecular Resources Research Infrastructure-NL (184.021.007) and the JNPD under the project PERADES (grant 733051021, Defining Genetic, Polygenic and Environmental Risk for Alzheimer's Disease Using Multiple Powerful Cohorts, Focused Epigenetics and Stem Cell metabolomics). This work has been performed as part of the CoSTREAM project (costream.eu), Memorabel program (project number 733050814) and has received funding from the European Union's Horizon 2020 research and innovation program under grant agreement 667375 . This work has been performed as part of the CardioVasculair Onderzoek Nederland (CVON 2012-03). Whitehall II: The Whitehall II study is supported by the Medical Research Council (MR/ R024227/1) and the British Heart Foundation (32334). M. Kivimaki is supported by the Medical Research Council (S011676/1), NordForsk, the Academy of Finland (311492), and Helsinki Institute of Life Science. The authors thank all of the participating civil service departments and their welfare, personnel, and establishment officers; the British Occupational Health and Safety Agency; the British Council of Civil Service Unions; all participating civil servants in the Whitehall II study; and all members of the Whitehall II study team. The Whitehall II Study team comprises research scientists, statisticians, study coordinators, nurses, data managers, administrative assistants, and data entry staff, who make the study possible. FINRISK97 and DILGOM: The FINRISK studies have received financial support from the National Institute for Health and Welfare and the Academy of Finland (139635) and the Finnish Foundation for Cardiovascular Research (to V.S). Additional funding has been obtained from the Academy of Finland (grants 297338, 307247), the Novo Nordisk Foundation (NNF17OC0026062), the Sigrid Juselius Foundation, and University of Oulu Graduate School. M.A.-K. is supported by a Senior Research Fellowship from the National Health and Medical Research Council of Australia (APP1158958). He also works in a unit that is supported by the University of Bristol and UK Medical Research Council (MC_UU_12013/1). The Baker Institute is supported in part by the Victorian Government's 
Operational Infrastructure Support Program. J.K. was supported through funds from the Academy of Finland (grants 297338 and 307247) and Novo Nordisk Fonden (grant NNF17OC0026062). PROSPER: This work (NMR) was supported by the European Federation of Pharmaceutical Industries Associations, Innovative Medicines Initiative Joint Undertaking, European Medical Information Framework grant 115372, and the European Commission under the Health Cooperation Work Programme of the 7th Framework Programme (grant 305507) "Heart 'omics' in AGEing" (HOMAGE). The PROSPER study was supported by an investigator-initiated grant obtained from Bristol-Myers Squibb. Dr. J.W. Jukema is an Established Clinical Investigator of the Netherlands Heart Foundation (grant 2001 D 032). EGCUT: This work was supported by Estonian Research Council (IUT20-60, PUT1660 to T.E., PUT1665 to K.F.); European Union Horizon 2020 (692145); European Union through the European Regional Development Fund (20142020.4.01.15-0012 GENTRANSMED, 2014-2020.4.2.2), and Estonian Center of Genomics/Roadmap II (project 20142020.4.01.16-0125). FHS: This work was supported by the National Heart, Lung and Blood Institute's FHS (contracts N01-HC-25195 and HHSN268201500001I). A portion of this research used the Linux Cluster for Genetic Analysis funded by the Robert Dawson Evans Endowment of the Department of Medicine at Boston University School of Medicine and Boston Medical Center. This work was also supported by grants from the National Institute of Neurological Disorders and Stroke (NS017950 and NS100605), the National Institute of Aging (AG033040, AG033193, AG054076, AG049607, AG008122, AG016495, U01-AG049505, and U01-AG052409), and the National Institute of Diabetes and Digestive and Kidney Diseases (DK-HL081572).

\section{Study Funding}

No targeted funding reported.

\section{Disclosure}

Dr. Dina Vojinovic, Ms. Marita Kalaoja, Dr. Stella Trompet, Dr. Krista Fischer, Mr. Martin J. Shipley, Dr. Shuo Li, Mr. Aki S. Havulinna, Dr. Markus Perola, Dr. Veikko Salomaa, Dr. Qiong Yang, Dr. Naveed Sattar, Dr. Pekka Jousilahti, Dr. Najaf Amin, Dr. Claudia L. Satizabal, Ms. Nele Taba, Dr. Behnam Sabayan, Dr. Ramachandran S. Vasan, Dr. M. Arfan Ikram, Dr. David J. Stott, Dr. Mika Ala-Korpela, Dr. J. Wouter Jukema, PhD, Dr. Sudha Seshadri, Dr. Mika Kivimaki, Dr. Tonu Esko, and Dr. Cornelia M. van Duijn report no disclosures. Dr. Johannes Kettunen possesses a modest amount of stock options of Nightingale Health Ltd, a company offering NMR metabolomics profiling. Go to Neurology.org/ $\mathrm{N}$ for full disclosures.

\section{Publication History}

Received by Neurology July 13, 2019. Accepted in final form October 28, 2020.
Appendix Authors

\begin{tabular}{|c|c|c|}
\hline Name & Location & Contribution \\
\hline $\begin{array}{l}\text { Dina Vojinovic, } \\
\text { PhD }\end{array}$ & $\begin{array}{l}\text { Erasmus MC University } \\
\text { Medical Center, } \\
\text { Rotterdam, the } \\
\text { Netherlands }\end{array}$ & $\begin{array}{l}\text { Design and conceptualized } \\
\text { study; analyzed and } \\
\text { interpreted the data; } \\
\text { drafted the manuscript for } \\
\text { intellectual content }\end{array}$ \\
\hline $\begin{array}{l}\text { Marita Kalaoja, } \\
\text { MSc }\end{array}$ & $\begin{array}{l}\text { University of Oulu and } \\
\text { Biocenter Oulu, Finland }\end{array}$ & $\begin{array}{l}\text { Analyzed the data; revised } \\
\text { the manuscript for } \\
\text { intellectual content }\end{array}$ \\
\hline $\begin{array}{l}\text { Stella Trompet, } \\
\text { PhD }\end{array}$ & $\begin{array}{l}\text { Leiden University } \\
\text { Medical Center, the } \\
\text { Netherlands }\end{array}$ & $\begin{array}{l}\text { Analyzed and interpreted } \\
\text { the data; revised the } \\
\text { manuscript for intellectual } \\
\text { content }\end{array}$ \\
\hline $\begin{array}{l}\text { Krista Fischer, } \\
\text { PhD }\end{array}$ & $\begin{array}{l}\text { University of Tartu, } \\
\text { Estonia }\end{array}$ & $\begin{array}{l}\text { Analyzed the data; revised } \\
\text { the manuscript for } \\
\text { intellectual content }\end{array}$ \\
\hline $\begin{array}{l}\text { Martin J. } \\
\text { Shipley, MSc }\end{array}$ & UCL, London, UK & $\begin{array}{l}\text { Contributed to acquisition } \\
\text { of data; analyzed and } \\
\text { interpreted the data; } \\
\text { revised the manuscript for } \\
\text { intellectual content }\end{array}$ \\
\hline
\end{tabular}

\begin{tabular}{ll}
\hline Shuo Li, PhD $\quad$ Boston University, MA & $\begin{array}{l}\text { Analyzed the data; revised } \\
\text { the manuscript for } \\
\text { intellectual content }\end{array}$
\end{tabular}

\begin{tabular}{lll}
\hline Aki S. & Finnish Institute for & Contributed to acquisition \\
Havulinna, PhD & $\begin{array}{l}\text { Health and Welfare, } \\
\text { Helsinki, Finland }\end{array}$ & $\begin{array}{l}\text { of data; revised the } \\
\text { manuscript for intellectual } \\
\end{array}$ \\
&
\end{tabular}

\begin{tabular}{lll}
\hline Markus Perola, & Finnish Institute for & Contributed to acquisition \\
PhD & Health and Welfare, & of data; revised the \\
& Helsinki, Finland & manuscript for intellectual \\
& & content
\end{tabular}

\begin{tabular}{lll}
\hline $\begin{array}{l}\text { Veikko } \\
\text { Salomaa, PhD }\end{array}$ & $\begin{array}{l}\text { Finnish Institute for } \\
\text { Health and Welfare, } \\
\text { Helsinki, Finland }\end{array}$ & $\begin{array}{l}\text { Contributed to acquisition } \\
\text { of data; revised the } \\
\text { manuscript for intellectual } \\
\text { content }\end{array}$ \\
\hline $\begin{array}{l}\text { Qiong Yang, } \\
\text { PhD }\end{array}$ & Boston University, MA & $\begin{array}{l}\text { Interpreted the data; } \\
\text { revised the manuscript for } \\
\text { intellectual content }\end{array}$
\end{tabular}

\begin{tabular}{|c|c|c|}
\hline $\begin{array}{l}\text { Naveed Sattar, } \\
\text { PhD }\end{array}$ & $\begin{array}{l}\text { Faculty of Medicine, } \\
\text { Glasgow, UK }\end{array}$ & $\begin{array}{l}\text { Contributed to acquisition of } \\
\text { data; revised the manuscript } \\
\text { for intellectual content }\end{array}$ \\
\hline $\begin{array}{l}\text { Pekka } \\
\text { Jousilahti, PhD }\end{array}$ & $\begin{array}{l}\text { Finnish Institute for } \\
\text { Health and Welfare, } \\
\text { Helsinki, Finland }\end{array}$ & $\begin{array}{l}\text { Interpreted the data; } \\
\text { revised the manuscript for } \\
\text { intellectual content }\end{array}$ \\
\hline $\begin{array}{l}\text { Najaf Amin, } \\
\text { PhD }\end{array}$ & $\begin{array}{l}\text { Erasmus MC University } \\
\text { Medical Center, } \\
\text { Rotterdam, the } \\
\text { Netherlands }\end{array}$ & $\begin{array}{l}\text { Interpreted the data; } \\
\text { revised the manuscript for } \\
\text { intellectual content }\end{array}$ \\
\hline $\begin{array}{l}\text { Claudia L. } \\
\text { Satizabal, PhD }\end{array}$ & $\begin{array}{l}\text { UT Health San Antonio, } \\
\text { TX }\end{array}$ & $\begin{array}{l}\text { Interpreted the data; } \\
\text { revised the manuscript for } \\
\text { intellectual content }\end{array}$ \\
\hline Nele Taba, MSc & $\begin{array}{l}\text { University of Tartu, } \\
\text { Estonia }\end{array}$ & $\begin{array}{l}\text { Interpreted the data; } \\
\text { revised the manuscript for } \\
\text { intellectual content }\end{array}$ \\
\hline $\begin{array}{l}\text { Behnam } \\
\text { Sabayan, PhD }\end{array}$ & $\begin{array}{l}\text { Northwestern } \\
\text { University, Chicago, IL }\end{array}$ & $\begin{array}{l}\text { Revised the manuscript } \\
\text { for intellectual content }\end{array}$ \\
\hline $\begin{array}{l}\text { Ramachandran } \\
\text { S. Vasan, MD }\end{array}$ & $\begin{array}{l}\text { Framingham Heart } \\
\text { Study, MA }\end{array}$ & $\begin{array}{l}\text { Interpreted the data; } \\
\text { revised the manuscript for } \\
\text { intellectual content }\end{array}$ \\
\hline
\end{tabular}


Appendix (continued)

\begin{tabular}{lll}
\hline Name & Location & Contribution \\
\hline $\begin{array}{l}\text { M. Arfan Ikram, } \\
\text { PhD }\end{array}$ & $\begin{array}{l}\text { Erasmus MC University } \\
\text { Medical Center, } \\
\text { Rotterdam, the } \\
\text { Netherlands }\end{array}$ & $\begin{array}{l}\text { Interpreted the data; } \\
\text { revised the manuscript for } \\
\text { intellectual content }\end{array}$ \\
\hline $\begin{array}{l}\text { David J. Stott, } \\
\text { MD }\end{array}$ & $\begin{array}{l}\text { University of Glasgow, } \\
\text { UK }\end{array}$ & $\begin{array}{l}\text { Contributed to acquisition } \\
\text { of data; revised the } \\
\text { manuscript for intellectual } \\
\text { content }\end{array}$
\end{tabular}

\begin{tabular}{lll}
\hline $\begin{array}{l}\text { Mika Ala- } \\
\text { Korpela, PhD }\end{array}$ & $\begin{array}{l}\text { University of Oulu and } \\
\text { Biocenter Oulu, Finland }\end{array}$ & $\begin{array}{l}\text { Interpreted the data; } \\
\text { revised the manuscript for } \\
\text { intellectual content }\end{array}$ \\
\hline
\end{tabular}

\begin{tabular}{|c|c|c|}
\hline $\begin{array}{l}\text { J. Wouter } \\
\text { Jukema, PhD }\end{array}$ & $\begin{array}{l}\text { Leiden University } \\
\text { Medical Center, the } \\
\text { Netherlands }\end{array}$ & $\begin{array}{l}\text { Contributed to acquisition } \\
\text { of data; revised the } \\
\text { manuscript for intellectual } \\
\text { content }\end{array}$ \\
\hline
\end{tabular}

\begin{tabular}{lll}
\hline Sudha Seshadri, & UT Health San Antonio, & $\begin{array}{l}\text { Interpreted the data; } \\
\text { revised the manuscript for } \\
\text { MD }\end{array}$ \\
& TX & intellectual content
\end{tabular}

\begin{tabular}{lll}
\hline Johannes & University of Oulu and & Interpreted the data; \\
Kettunen, PhD & Biocenter Oulu, Finland & $\begin{array}{l}\text { revised the manuscript for } \\
\text { intellectual content }\end{array}$
\end{tabular}

Mika Kivimaki, UCL, London, UK
FMedSci

Contributed to acquisition of data; interpreted the data; revised the manuscript for intellectual content

\begin{tabular}{lll}
\hline Tonu Esko, PhD & $\begin{array}{l}\text { University of Tartu, } \\
\text { Estonia }\end{array}$ & $\begin{array}{l}\text { Interpreted the data; } \\
\text { revised the manuscript for } \\
\text { intellectual content }\end{array}$ \\
\hline $\begin{array}{l}\text { Cornelia M. van } \\
\text { Duijn, PhD }\end{array}$ & University of Oxford, UK & $\begin{array}{l}\text { Design and } \\
\text { conceptualized study; } \\
\text { interpreted data; drafted } \\
\text { the manuscript for } \\
\text { intellectual content }\end{array}$ \\
\hline
\end{tabular}

\section{References}

1. Mozaffarian D, Benjamin EJ, Go AS, et al. Heart disease and stroke statistics-2015 update: a report from the American Heart Association. Circulation 2015;131: e29-e322.

2. Andersen KK, Olsen TS, Dehlendorff C, Kammersgaard LP. Hemorrhagic and ischemic strokes compared: stroke severity, mortality, and risk factors. Stroke 2009;40: 2068-2072.

3. Goldstein LB, Bushnell CD, Adams RJ, et al. Guidelines for the primary prevention of stroke: a guideline for healthcare professionals from the American Heart Association/ American Stroke Association. Stroke 2011;42:517-584.

4. Zhang Y, Tuomilehto J, Jousilahti P, Wang Y, Antikainen R, Hu G. Total and highdensity lipoprotein cholesterol and stroke risk. Stroke 2012;43:1768-1774.

5. Amarenco P, Labreuche J, Touboul PJ. High-density lipoprotein-cholesterol and risk of stroke and carotid atherosclerosis: a systematic review. Atherosclerosis 2008;196: 489-496.

6. Saenger AK, Christenson RH. Stroke biomarkers: progress and challenges for diagnosis, prognosis, differentiation, and treatment. Clin Chem 2010;56:21-33.

7. Makin SD, Doubal FN, Dennis MS, Wardlaw JM. Clinically confirmed stroke with negative diffusion-weighted imaging magnetic resonance imaging: longitudinal study of clinical outcomes, stroke recurrence, and systematic review. Stroke 2015;46: 3142-3148.

8. Jung JY, Lee HS, Kang DG, et al. 1H-NMR-based metabolomics study of cerebral infarction. Stroke 2011;42:1282-1288.

9. Wang D, Kong J, Wu J, Wang X, Lai M. GC-MS-based metabolomics identifies an amino acid signature of acute ischemic stroke. Neurosci Lett 2017;642:7-13.

10. Lee Y, Khan A, Hong S, Jee SH, Park YH. A metabolomic study on high-risk stroke patients determines low levels of serum lysine metabolites: a retrospective cohort study. Mol Biosyst 2017;13:1109-1120.

11. Holmes MV, Millwood IY, Kartsonaki C, et al. Lipids, lipoproteins, and metabolites and risk of myocardial infarction and stroke. J Am Coll Cardiol 2018;71:620-632.
12. Wieberdink RG, Ikram MA, Hofman A, Koudstaal PJ, Breteler MMB. Trends in stroke incidence rates and stroke risk factors in Rotterdam, the Netherlands from 1990 to 2008. Eur J Epidemiol 2012;27:287-295.

13. Kivimaki M, Batty GD, Singh-Manoux A, Britton A, Brunner EJ, Shipley MJ. Validity of cardiovascular disease event ascertainment using linkage to UK hospital records. Epidemiology 2017;28:735-739.

14. Britton A, Milne B, Butler T, et al. Validating self-reported strokes in a longitudinal UK cohort study (Whitehall II): extracting information from hospital medical records versus the Hospital Episode Statistics database. BMC Med Res Methodol 2012;12:83.

15. Shepherd J, Blauw GJ, Murphy MB, et al. The design of a Prospective Study of Pravastatin in the Elderly at Risk (PROSPER). Am J Cardiol 1999;84:1192-1197.

16. Carandang R, Seshadri S, Beiser A, et al. Trends in incidence, lifetime risk, severity, and 30-day mortality of stroke over the past 50 years. JAMA 2006;296:2939-2946.

17. Seshadri S, Beiser A, Kelly-Hayes M, et al. The lifetime risk of stroke: estimates from the Framingham study. Stroke 2006;37:345-350

18. Soininen P, Kangas AJ, Wurtz P, Suna T, Ala-Korpela M. Quantitative serum nuclear magnetic resonance metabolomics in cardiovascular epidemiology and genetics. Circ Cardiovasc Gene 2015;8:192-206.

19. Soininen P, Kangas AJ, Wurtz P, et al. High-throughput serum NMR metabonomics for cost-effective holistic studies on systemic metabolism. Analyst 2009;134:1781-1785.

20. Freedman DS, Otvos JD, Jeyarajah EJ, et al. Sex and age differences in lipoprotein subclasses measured by nuclear magnetic resonance spectroscopy: the Framingham study. Clin Chem 2004;50:1189-1200.

21. Kathiresan S, Manning AK, Demissie S, et al. A genome-wide association study for blood lipid phenotypes in the Framingham Heart Study. BMC Med Genet 2007; 8(suppl 1):S17.

22. Delles C, Rankin NJ, Boachie C, et al. Nuclear magnetic resonance-based metabolomics identifies phenylalanine as a novel predictor of incident heart failure hospitalisation: results from PROSPER and FINRISK 1997. Eur J Heart Fail 2018;20: 663-673.

23. Akbaraly T, Wurtz P, Singh-Manoux A, et al. Association of circulating metabolites with healthy diet and risk of cardiovascular disease: analysis of two cohort studies. Sci Rep 2018;8:8620.

24. Kettunen J, Demirkan A, Wurtz P, et al. Genome-wide study for circulating metabolites identifies 62 loci and reveals novel systemic effects of LPA. Nat Commun 2016;7:11122.

25. van der Lee SJ, Teunissen CE, Pool R, et al. Circulating metabolites and general cognitive ability and dementia: evidence from 11 cohort studies. Alzheimers Dement 2018;14:707-722.

26. Willer CJ, Li Y, Abecasis GR. METAL: fast and efficient meta-analysis of genomewide association scans. Bioinformatics 2010;26:2190-2191.

27. Higgins JP, Thompson SG, Deeks JJ, Altman DG. Measuring inconsistency in metaanalyses. BMJ 2003;327:557-560.

28. $\mathrm{Li} \mathrm{J}$, Ji L. Adjusting multiple testing in multilocus analyses using the eigenvalues of a correlation matrix. Heredity 2005;95:221-227.

29. Ignesti G, Pino R, Banchelli G, Ferrali C, Pirisino R, Raimondi L. Increased desensitization by picomolar phorbol ester of the endothelium-mediated effect of histamine in the perfused rat mesenteric bed. Inflamm Res 1996;45:171-175.

30. Wang L, Liu S, Yang W, et al. Plasma amino acid profile in patients with aortic dissection. Sci Rep 2017;7:40146.

31. Toba H, Nakamori A, Tanaka Y, et al. Oral L-histidine exerts antihypertensive effects via central histamine $\mathrm{H} 3$ receptors and decreases nitric oxide content in the rostral ventrolateral medulla in spontaneously hypertensive rats. Clin Exp Pharmacol Physiol 2010;37:62-68.

32. Tuttle KR, Milton JE, Packard DP, Shuler LA, Short RA. Dietary amino acids and blood pressure: a cohort study of patients with cardiovascular disease. Am J Kidney Dis 2012;59:803-809.

33. Jennings A, MacGregor A, Welch A, Chowienczyk P, Spector T, Cassidy A. Amino acid intakes are inversely associated with arterial stiffness and central blood pressure in women. J Nutr 2015;145:2130-2138.

34. Watanabe M, Suliman ME, Qureshi AR, et al. Consequences of low plasma histidine in chronic kidney disease patients: associations with inflammation, oxidative stress, and mortality. Am J Clin Nutr 2008;87:1860-1866.

35. Feng RN, Niu YC, Sun XW, et al. Histidine supplementation improves insulin resistance through suppressed inflammation in obese women with the metabolic syndrome: a randomised controlled trial. Diabetologia 2013;56:985-994.

36. Adachi N, Liu K, Arai T. Prevention of brain infarction by postischemic administration of histidine in rats. Brain Res 2005;1039:220-223.

37. Liao RJ, Jiang L, Wang RR, et al. Histidine provides long-term neuroprotection after cerebral ischemia through promoting astrocyte migration. Sci Rep 2015;5:15356.

38. Gray LR, Tompkins SC, Taylor EB. Regulation of pyruvate metabolism and human disease. Cell Mol Life Sci 2014;71:2577-2604.

39. Wang $\mathrm{Q}$ van Hoecke $\mathrm{M}$, Tang $\mathrm{XN}$, et al. Pyruvate protects against experimental stroke via an anti-inflammatory mechanism. Neurobiol Dis 2009;36:223-231.

40. Ryou MG, Liu R, Ren M, Sun J, Mallet RT, Yang SH. Pyruvate protects the brain against ischemia-reperfusion injury by activating the erythropoietin signaling pathway. Stroke 2012;43:1101-1107.

41. Wurtz P, Havulinna AS, Soininen P, et al. Metabolite profiling and cardiovascular event risk: a prospective study of 3 population-based cohorts. Circulation 2015;131:774-785

42. Connelly MA, Gruppen EG, Otvos JD, Dullaart RPF. Inflammatory glycoproteins in cardiometabolic disorders, autoimmune diseases and cancer. Clin Chim Acta 2016;459:177-186.

43. Lawler PR, Akinkuolie AO, Chandler PD, et al. Circulating N-linked glycoprotein acetyls and longitudinal mortality risk. Circ Res 2016;118:1106-1115.

44. Wang TJ, Larson MG, Vasan RS, et al. Metabolite profiles and the risk of developing diabetes. Nat Med 2011;17:448-453. 
45. Floegel A, Stefan N, Yu ZH, et al. Identification of serum metabolites associated with risk of type 2 diabetes using a targeted metabolomic approach. Diabetes 2013;62: 639-648.

46. Au A. Metabolomics and lipidomics of ischemic stroke. Adv Clin Chem 2018;85: 31-69.

47. Yang L, Lv P, Ai WP, et al. Lipidomic analysis of plasma in patients with lacunar infarction using normal-phase/reversed-phase two-dimensional liquid chromatography-quadrupole time-of-flight mass spectrometry. Anal Bioanal Chem 2017;409:3211-3222.

48. Chei CL, Yamagishi K, Kitamura A, et al. High-density lipoprotein subclasses and risk of stroke and its subtypes in Japanese population: the Circulatory Risk in Communities study. Stroke 2013;44:327-333.

49. Ditah C, Otvos J, Nassar H, Shaham D, Sinnreich R, Kark JD. Small and medium sized HDL particles are protectively associated with coronary calcification in a crosssectional population-based sample. Atherosclerosis 2016;251:124-131.

50. Du XM, Kim MJ, Hou LM, et al. HDL particle size is a critical determinant of ABCA1mediated macrophage cellular cholesterol export. Circ Res 2015;116:1133-1142.

51. Kontush A, Chantepie S, Chapman MJ. Small, dense HDL particles exert potent protection of atherogenic LDL against oxidative stress. Arterioscl Throm Vas 2003; 23:1881-1888.

52. Kim DS, Li YK, Bell GA, et al. Concentration of smaller high-density lipoprotein particle (HDL-P) is inversely correlated with carotid intima media thickening after confounder adjustment: the Multi Ethnic Study of Atherosclerosis (MESA). J Am Heart Assoc 2016;5:e002977.
53. Kontush A, Therond P, Zerrad A, et al. Preferential sphingosine-1-phosphate enrichment and sphingomyelin depletion are key features of small dense HDL3 particles: relevance to antiapoptotic and antioxidative activities. Arterioscl Throm Vas 2007;27:1843-1849.

54. Saeed A, Feofanova EV, Yu B, et al. Remnant-like particle cholesterol, low-density lipoprotein triglycerides, and incident cardiovascular disease. J Am Coll Cardiol 2018; 72:156-169.

55. Marz W, Scharnagl H, Winkler K, et al. Low-density lipoprotein triglycerides associated with low-grade systemic inflammation, adhesion molecules, and angiographic coronary artery disease: the Ludwigshafen Risk and Cardiovascular Health study. Circulation 2004;110:3068-3074.

56. Wishart DS, Jewison T, Guo AC, et al. HMDB 3.0: the human metabolome database in 2013. Nucleic Acids Res 2013;41:D801-D807.

57. Jimenez B, Holmes E, Heude C, et al. Quantitative lipoprotein subclass and low molecular weight metabolite analysis in human serum and plasma by (1)H NMR spectroscopy in a multilaboratory trial. Anal Chem 2018;90:11962-11971.

58. Deelen J, Kettunen J, Fischer K, et al. A metabolic profile of all-cause mortality risk identified in an observational study of 44,168 individuals. Nat Commun 2019;10: 3346.

59. Sliz E, Kettunen J, Holmes MV, et al. Metabolomic consequences of genetic inhibition of PCSK9 compared with statin treatment. Circulation 2018;138:2499-2512.

60. van der Lee SJ, Teunissen CE, Pool R, et al. Circulating metabolites and general cognitive ability and dementia: Evidence from 11 cohort studies. Alzheimers Dement 2018; 14:707-722. 


\section{Neurology}

\section{Association of Circulating Metabolites in Plasma or Serum and Risk of Stroke: Meta-analysis From 7 Prospective Cohorts \\ Dina Vojinovic, Marita Kalaoja, Stella Trompet, et al.}

Neurology 2021;96;e1110-e1123 Published Online before print December 2, 2020

DOI 10.1212/WNL.0000000000011236

This information is current as of December 2, 2020

\section{Updated Information \&} Services

References

Citations

Subspecialty Collections

Permissions \& Licensing

Reprints including high resolution figures, can be found at: http://n.neurology.org/content/96/8/e1110.full

This article cites 60 articles, 24 of which you can access for free at: http://n.neurology.org/content/96/8/e1110.full\#ref-list-1

This article has been cited by 1 HighWire-hosted articles: http://n.neurology.org/content/96/8/e1110.full\#\#otherarticles

This article, along with others on similar topics, appears in the following collection(s):

\section{All Cerebrovascular disease/Stroke}

http://n.neurology.org/cgi/collection/all_cerebrovascular_disease_strok $\mathrm{e}$

\section{Cohort studies}

http://n.neurology.org/cgi/collection/cohort_studies

Information about reproducing this article in parts (figures,tables) or in its entirety can be found online at:

http://www.neurology.org/about/about_the_journal\#permissions

Information about ordering reprints can be found online:

http://n.neurology.org/subscribers/advertise

Neurology ${ }^{\circledR}$ is the official journal of the American Academy of Neurology. Published continuously since 1951 , it is now a weekly with 48 issues per year. Copyright Copyright (C) 2020 The Author(s). Published by Wolters Kluwer Health, Inc. on behalf of the American Academy of Neurology.. All rights reserved. Print ISSN: 0028-3878. Online ISSN: 1526-632X.

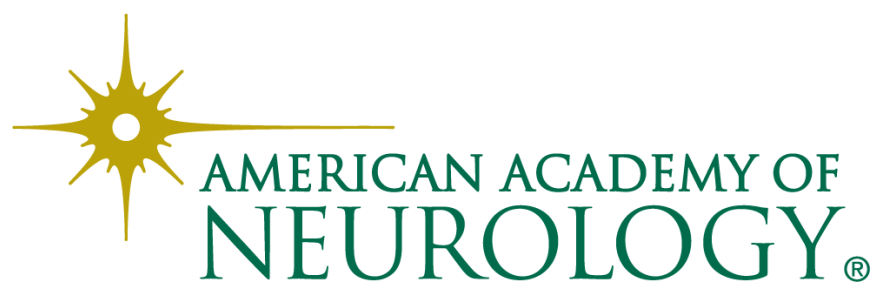

